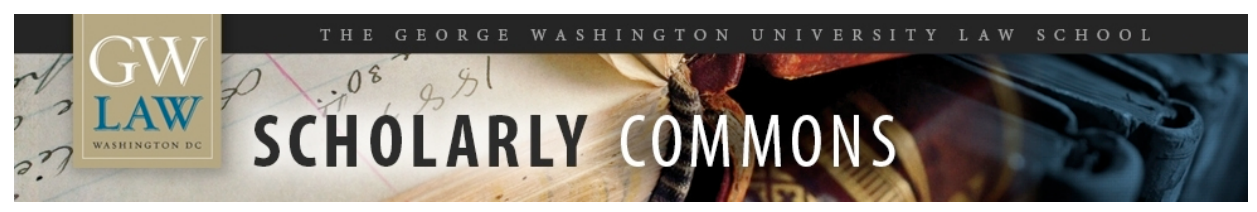

GW Law Faculty Publications \& Other Works

Faculty Scholarship

2003

\title{
The Supremacy Clause as a Constraint on Federal Power
}

Bradford R. Clark

George Washington University Law School, bclark@law.gwu.edu

Follow this and additional works at: https://scholarship.law.gwu.edu/faculty_publications

Part of the Law Commons

\section{Recommended Citation}

Bradford R. Clark, The Supremacy Clause as a Constraint on Federal Power, 71 Geo. Wash. L. Rev. 91 (2003).

This Article is brought to you for free and open access by the Faculty Scholarship at Scholarly Commons. It has been accepted for inclusion in GW Law Faculty Publications \& Other Works by an authorized administrator of Scholarly Commons. For more information, please contact spagel@law.gwu.edu. 


\title{
The Supremacy Clause as a Constraint on Federal Power
}

\author{
Bradford R. Clark ${ }^{*}$
}

It is . . not entirely unworthy of observation, that in declaring what shall be the supreme law of the land, the constitution itself is first mentioned; and not the laws of the United States generally, but those only which shall be made in pursuance of the constitution, have that rank. ${ }^{1}$

Introduction

Today, it is widely accepted that the Constitution authorizes courts to review and invalidate state laws that conflict with federal statutes. At the same time, prominent commentators and even some judges maintain that courts should not seriously review the constitutionality of federal statutes alleged to exceed the scope of Congress' enumerated powers. Opponents of such review offer two grounds for this dichotomy. First, they argue that the Constitution specifically directs courts to uphold "the supreme Law of the Land" notwithstanding state law "to the Contrary," ${ }^{2}$ but contains no express authority for courts to enforce the limits of federal power. Second, they invoke the political safeguards of federalism - that is, "the role of the states in the composition and selection of the central government." ${ }^{3}$ In their view, the constitutional structure protects the states (and thereby reduces the need for judicial review of federal power), but establishes no comparable safeguards to deter states from interfering with federal prerogatives. ${ }^{4}$

Contrary to these arguments, however, there is an express textual basis for judicial review of

\footnotetext{
*Professor of Law, The George Washington University Law School. I thank Vik Amar, Rachel Barkow, Evan Caminker, Philip Hamburger, Matt Harrington, Bill Kelley, Larry Kramer, John Manning, Jon Molot, Henry Monaghan, Caleb Nelson, Sai Prakash, Jon Siegel, Peter Smith, Adrian Vermeule, John Yoo, and Ernie Young for insightful comments, and the G.W. faculty for valuable suggestions at a faculty workshop. I also thank Jeremy Stein and Brian Wesoloski for excellent research assistance.

${ }^{1}$ Marbury v. Madison, 5 U.S. (1 Cranch) 137, 180 (1803).

${ }^{2}$ U.S. CONST. art. VI, cl. 2.

${ }^{3}$ Herbert Wechsler, The Political Safeguards of Federalism: The Role of the States in the Composition and Selection of the National Government, 54 COLUM. L. REV. 543, 558 (1954).

${ }^{4}$ See Jesse H. Choper, Judicial Review and the National Political Process: A Functional RECONSIDERATION OF THE ROLE OF THE SUPREME COURT (1980); Jesse H. Choper, The Scope of National Power Vis-à-Vis the States: The Dispensability of Judicial Review, 86 YALE L.J. 1552 (1977); Larry D. Kramer, The Supreme Court, 2000 Term-Foreword: We the Court, 115 HARV. L. REV. 4 (2001) [hereinafter Kramer, We the Court]; Larry D. Kramer, Putting the Politics Back into the Political Safeguards of Federalism, 100 ColuM. L. REV. 215 (2000) [hereinafter Kramer, Politics].
} 
federal statutes alleged to exceed Congress' enumerated powers. The Supremacy Clause establishes a rule of decision for courts adjudicating the rights and duties of parties under both state and federal law. As the Supreme Court has recognized, "under our federal system, the States possess sovereignty concurrent with that of the Federal Government, subject only to limitations imposed by the Supremacy Clause." ${ }^{5}$ The Clause, in turn, designates as "the supreme Law of the Land" only those "Laws of the United States ... made in Pursuance" of the Constitution. ${ }^{6}$ If a federal statute satisfies this condition, courts must apply the statute notwithstanding contrary state law. If the federal statute fails this condition, however, it does not qualify as "the supreme Law of the Land" and courts remain free to apply state law. Thus, in order to apply the Supremacy Clause, courts must necessarily consider and resolve challenges to the constitutionality of federal statutes.

The text, history, and structure of the Constitution confirm that the Supremacy Clause authorizes judicial review of federal statutes alleged to exceed the scope of federal power. ${ }^{7}$ The Founders considered three alternative mechanisms for resolving conflicts between state and federal law: coercive military force, congressional power to negative state laws, and adjudication under the Supremacy Clause. The decision to enlist courts—rather than Congress or the President—indicates that the Founders preferred to treat conflicts between state and federal law as judicial, rather than political questions. In addition, by expressly conditioning the supremacy of federal statutes on their constitutionality, the Supremacy Clause reassured the states that courts (both federal and state) would keep the federal government within the bounds of its assigned powers. Thus, in effect, the Clause reserves all remaining powers to the states, or to the people. ${ }^{8}$

This Article has four Parts. Part I describes the apparent double standard of judicial review in federalism cases, under which courts vigorously review state law alleged to conflict with federal statutes but decline to subject federal statutes alleged to exceed the scope of Congress' enumerated powers to serious constitutional scrutiny. Part II examines the text, history, and structure of the Constitution and concludes that the Supremacy Clause conditions the supremacy of federal statutes on their constitutionality. Part III reassesses the double standard of judicial review in light of the conditional nature of the Supremacy Clause. Contrary to recent scholarship, this Part concludes that the Constitution expressly authorizes courts to identify "the supreme Law of the Land" by determining whether federal statutes invoked by the parties were "made in Pursuance" of the Constitution. Finally, Part IV finds support for these conclusions in the Supreme Court's early invocation of the Supremacy Clause to support judicial review of federal statutes in cases like

${ }^{5}$ Tafflin v. Levitt, 493 U.S. 455, 458 (1990).

${ }^{6}$ U.S. CONST. art. VI, cl. 2. "Laws" in this context refer to measures enacted by Congress pursuant to Article I, Section 7. See Bradford R. Clark, Separation of Powers as a Safeguard of Federalism, 79 TEX. L. REV. 1321, 1334-36 (2001) [hereinafter Clark, Separation of Powers].

${ }^{7}$ This Article examines the text, history, and structure of the Constitution not to suggest that such sources are necessarily determinative of constitutional meaning, but to refute suggestions by commentators that the Founders did not understand the Constitution to authorize judicial review of the scope of federal power.

${ }^{8}$ Cf. U.S. CONST. amend. X. In this sense, the Tenth Amendment-adopted after the Supremacy Clausestates "but a truism" inherent in the original Constitution. United States v. Darby, 312 U.S. 100, 124 (1941). 
McCulloch v. Maryland ${ }^{9}$ and Gibbons v. Ogden. ${ }^{10}$

\section{The Double Standard of Judicial Review in Federalism Cases}

The modern tendency to overlook the Supremacy Clause as a textual basis for judicial review of both state and federal statutes has facilitated the development of a double standard of judicial review. The Supreme Court has long invoked the Clause to invalidate state law that conflicts with federal statutes or that "stands as an obstacle to the accomplishment and execution of the full purposes and objectives of Congress." ${ }^{11}$ At the same time, the Court has generally upheld increasingly expansive exercises of congressional power, and suggested that there are few-if anyjudicially enforceable limits on such power. ${ }^{12}$

Commentators have attempted to justify this double standard of judicial review largely by invoking the political safeguards of federalism and embracing a one-sided view of the Supremacy Clause. For example, Herbert Wechsler observed that "the national political process in the United States - and especially the role of the states in the composition and selection of the central government-is intrinsically well adapted to retarding or restraining new intrusions by the center on the domain of the states." ${ }^{13}$ Professor Wechsler did not go so far as to deny the existence of judicial review, but he suggested that such "political safeguards of federalism" warrant judicial deference to Congress' view of its own powers. As he put it, "the Court is on weakest ground when it opposes its interpretation of the Constitution to that of Congress in the interest of the states, whose representatives control the legislative process and, by hypothesis, have broadly acquiesced in sanctioning the challenged Act of Congress." ${ }^{14}$ At the same time, Wechsler defended more vigorous scrutiny of state law under the Supremacy Clause. He reasoned that the "prime function envisaged for judicial review —in relation to federalism — was the maintenance of national supremacy against nullification or usurpation by the individual states, the national government having no part in their composition or their councils." ${ }^{15}$

\footnotetext{
${ }^{9}$ McCulloch v. Maryland, 17 U.S. (4 Wheat.) 316 (1819).

${ }^{10}$ Gibbons v. Ogden, 22 U.S. (9 Wheat.) 1 (1824).
}

${ }^{11}$ Hines v. Davidowitz, 312 U.S. 52, 67 (1941); see also Rice v. Santa Fe Elevator Corp., 331 U.S. 218, 230 (1947) (endorsing preemption when a federal statute touches "a field in which the federal interest is so dominant that the federal system will be assumed to preclude enforcement of state laws on the same subject").

${ }^{12}$ See, e.g., Wickard v. Filburn, 317 U.S. 111 (1942).

${ }^{13}$ Wechsler, supra note 3, at 558.

${ }^{14} I d$. at 559. Unlike his successors, Professor Wechsler specifically recognized the relationship between the Supremacy Clause and judicial review of the scope of federal power. See id. ("This is not to say that the Court can decline to measure national enactments by the Constitution when it is called upon to face the question in the course of ordinary litigation; the supremacy clause governs there as well."). For a discussion of Professor Wechsler's subsequent and more expansive explanation of the constitutional basis for judicial review, see infra notes 147-51 and accompanying text.

\footnotetext{
${ }^{15}$ Wechsler, supra note 3, at 559.
} 
Several decades later, Jesse Choper restated and expanded Professor Wechsler's thesis. Choper urged courts to distinguish sharply between judicial review of federal statutes and judicial review of state law. In Professor Choper's view, "the constitutional issue whether federal action is beyond the authority of the central government and thus violates 'states' rights' should be treated as nonjusticiable, with final resolution left to the political branches." ${ }^{16}$ Choper's rationale was both structural and strategic. Like Wechsler, Choper relied on the states' role in selecting Congress and the President. In addition, he argued that dispensing with judicial review in favor of the states "would husband the Supreme Court's scarce political capital, and thus would enhance the Justices' ability to act in support of personal liberties." ${ }^{17}$ According to Professor Choper, these arguments do not apply to judicial review of state law because "the predominant role envisaged for the Court in this area was to prevent state encroachments on national supremacy." ${ }^{18}$ Choper reasoned that "the people of all the States, and the States themselves, are represented in Congress,"' but that "[s]tate and local legislatures contain no such representatives of the central government."19

Even on its own terms, the political safeguards approach suggested by Professors Wechsler and Choper is open to serious question. Lewis Kaden was the first to point out that changed circumstances have diluted whatever protection the political safeguards may have once afforded the states. $^{20}$ These changes include the direct election of senators under the Seventeenth Amendment, popular election of presidential electors in each state, and increasing constraints on the states' ability to draw congressional districts and set voter qualifications. ${ }^{21}$ Such changes have undermined the

\footnotetext{
${ }^{16}$ Choper, supra note 4, at 1557.

${ }^{17}$ Id. at 1577 .

${ }^{18}$ CHOPER, supra note 4, at 205.
}

${ }^{19}$ Id. at 206 (quoting McCulloch v. Maryland, 17 U.S. 316, 435 (1819)). The assumption that the federal government lacks influence over composition and selection of state governments is now open to question. Although the original Constitution gave the federal government virtually no role in the composition of state governments, subsequent legal developments—such as the Civil War amendments, the Voting Rights Act, and judicial decisions - have given the federal government increasing influence over state districting and voter qualifications. Were courts to accept the political safeguards approach, these changes might counsel against judicial review of state law. At the same time, various legal developments have steadily reduced the states' ability to influence the composition and selection of the federal government. See infra notes 21-25 and accompanying text.

${ }^{20}$ See Lewis B. Kaden, Politics, Money, and State Sovereignty: The Judicial Role, 79 CoLuM. L. REV. 847, 860-68 (1979). In addition, Henry Monaghan has observed that "Choper's empirical argument that adjudicating claims of this sort weakens the Court's ability to protect civil liberties seems entirely speculative and out of touch with the flow of our constitutional history." Henry P. Monaghan, Book Review, 94 HARV. L. REV. 296, 301 (1980).

${ }^{21}$ See Clark, Separation of Powers, supra note 6, at 1369 (explaining that "changed circumstances have undermined the political safeguards of federalism inherent in the original constitutional scheme"); Michael C. Dorf, No Federalists Here: Anti-Federalism and Nationalism on the Rehnquist Court, 31 RUTGERS L.J. 741, 747 (2000) (explaining that "with the Seventeenth Amendment's shift to the direct election of senators and the general nationalization of congressional politics, members of Congress are not especially tethered to their 
efficacy of the political safeguards and make substitution of such safeguards for judicial review

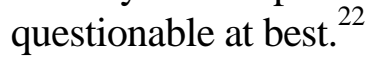

More fundamentally, John Yoo has made a strong case that the history and structure of the Constitution establish the propriety of judicial review to police the bounds of federal power. Relying on sources from the founding era, Professor Yoo concludes that the "political safeguards argument is an ahistorical one."23 According to Yoo, examination of the historical materials supports the conclusion that "the Framers - both Federalists and Anti-Federalists-understood the text and structure of the Constitution to permit judicial review in cases questioning the scope of federal power." ${ }^{24}$ More recently, Professors Prakash and Yoo have argued that the political safeguards of federalism are not "perfect safeguard[s] of federalism," and that judicial review was meant to "play backup to Congress, to ensure that any unconstitutional legislation that emerges from the political process ... . will not survive." ${ }^{25}$

Attempting to sidestep the force of these criticisms, Larry Kramer has urged the expansion of the political safeguards approach to encompass mechanisms outside the original constitutional structure. Professor Kramer acknowledges that "subsequent experience and later developments have robbed [Wechsler's] analysis of much, if not all, of its force." ${ }^{26}$ Nonetheless, Kramer essentially maintains that Professor Wechsler was right for the wrong reasons. ${ }^{27}$

states"); Steven G. Calabresi, "A Government of Limited and Enumerated Powers": In Defense of United States v. Lopez, 94 MiCH. L. REV. 752, 794 (1995) (arguing that the political safeguards approach is "hopelessly out of touch with the realities of the modern political process"); see also Lynn A. Baker \& Ernest A. Young, Federalism and the Double Standard of Judicial Review, 51 DuKE L.J. 75, 87-133 (arguing in favor of judicial review in federalism cases and refuting various rationales for leaving such questions to the political process); Lynn A. Baker, Putting the Safeguards Back Into the Political Safeguards of Federalism, 46 VILL. L. REV. 951, 961-962 (2001) (questioning whether the political safeguards of federalism are capable of protecting states against "horizontal aggrandizement"- that is, the attempt by some states "to use federal power as an instrument for imposing their preferences on other states").

${ }^{22}$ The Court itself has further undermined the political safeguards of federalism by invalidating both state attempts to limit the number of terms that senators and representatives may serve, see U.S. Term Limits, Inc. v. Thornton, 514 U.S. 779 (1995), and state attempts to instruct senators and representatives how to vote on a proposed constitutional amendment establishing congressional term limits, see Cook v. Gralike, 531 U.S. 510 (2001).

${ }^{23}$ John C. Yoo, The Judicial Safeguards of Federalism, 70 S. CAL. L. REV. 1311, 1357 (1997).

${ }^{24}$ Id. at 1391.

${ }^{25}$ Saikrishna B. Prakash \& John C. Yoo, The Puzzling Persistence of Process-Based Federalism Theories, 79 Tex. L. ReV. 1459, 1479 (2001) [hereinafter Prakash \& Yoo, Puzzling Persistence]. For a more comprehensive explanation of the origins of judicial review, see Saikrishna B. Prakash \& John C. Yoo, The Origins of Judicial Review, 70 U. CHI. L. REV. (forthcoming Summer 2003) [hereinafter Prakash \& Yoo, Origins of Judicial Review].

${ }^{26}$ Kramer, Politics, supra note 4, at 218.

${ }^{27} I d$. at 219 ("The basic intuition of Wechsler's pathbreaking article thus remains sound, even if the reasons for its vitality are not those offered by Professor Wechsler himself."). 
Rather than the formal constitutional structures highlighted in Wechsler's original analysis, federalism in the United States has been safeguarded by a complex system of informal political institutions (of which political parties have historically been the most important) - institutions that were not part of the original design, but have nevertheless served to fulfill its objectives. ${ }^{28}$

Political parties, he contends, "protected the states by making national officials dependent upon state and local party organizations." ${ }^{29}$ In addition, Kramer asserts that "no one in the Founding generation would have imagined that courts could or should play a prominent role in defining the limits of federal power." ${ }^{30}$ Thus, Kramer concludes that the original understanding of judicial review, combined with the extra-constitutional mechanisms he identifies, allow the Supreme Court to apply no more than "rational basis scrutiny to questions regarding the limits of Congress' power under Article I." ${ }^{31}$

At the same time, Professor Kramer embraces more vigorous judicial review of state law. In so doing, Kramer has presumably concluded that extra-constitutional mechanisms like political

\footnotetext{
${ }^{28}$ Id. See also Daniel J. Meltzer, State Sovereign Immunity: Five Authors in Search of a Theory, 75 NOTRE DAME L. REV. 1011, 1024 (2000) ("[T]he political safeguards today are strongly buttressed by, if not primarily located in, a complex web of extra-constitutional political institutions (like political parties and organizations representing state and local governments) and complex connections among officials in parties, organizations, and the various levels of governments.").

${ }^{29}$ Kramer, Politics, supra note 4, at 278. Kramer's suggestion is that dependence on state and local political parties makes federal elected officials sensitive to local concerns. Such officials are well positioned to safeguard state prerogatives because federal lawmaking procedures "assign lawmaking functions solely to the federal elected officials that Kramer identifies as indebted to the states (i.e., the President and members of the House and Senate)." Bradford R. Clark, Putting the Safeguards Back into the Political Safeguards of Federalism, 80 TEX. L. REV. 327, 337 (2001). It follows that commentators who rely on the political safeguards to restrict judicial review in federalism cases should embrace judicial review to enforce the exclusivity of federal lawmaking procedures. The reason is simple. "If the federal government were free to evade federal lawmaking procedures by shifting substantial lawmaking authority to unelected officials (such as independent agencies or federal courts), then Kramer's argument . . . would lose much, if not all, of its force." Id. Therefore, there is substantial tension, for example, between Professor Choper's proposals to treat both federalism and separation-of-powers questions as nonjusticiable. See CHOPER, supra note 4, at 175, 263.

${ }^{30}$ Kramer, Politics, supra note 4, at 235. Contrary to Professor Kramer's suggestion, the rise of political parties may have actually undermined-rather than facilitated - the states' ability to keep the federal government within the limits of its enumerated powers. Because state officials are so closely aligned with national political parties, they may frequently fail to fight for the governance prerogatives of the states in order to support federal initiatives favored by the parties.
}

${ }^{31} I$. at 291. See also Evan H. Caminker, State Sovereignty and Subordinacy: May Congress Commandeer State Officers to Implement Federal Law?, 95 COLUM. L. REV. 1001, 1086 (1995) ("[T]here is reason to believe that the concerns for state autonomy are effectively voiced in the national political process."). 
parties do not suffice to protect the federal government from state interference. ${ }^{32}$ Kramer's $^{\text {' }}$ explanation for distinguishing judicial review of state and federal law is that "[t]he subject of judicial review did come up in Philadelphia, but in connection with the problem of controlling the states, not Congress." ${ }^{33}$ In Kramer's view, "the Supremacy Clause indicates that the Framers believed courts could play a role in enforcing the Constitution against the states," but says nothing about judicial review of federal statutes alleged to exceed the scope of Congress' enumerated powers. ${ }^{34}$

These commentators are not alone in urging a double standard of judicial review. In recent years, some members of the Supreme Court have invoked the political safeguards of federalism to justify lax judicial review of federal statutes, while continuing to subject state statutes to searching judicial scrutiny. In Garcia v. San Antonio Metropolitan Transit Authority, ${ }^{35}$ for example, the Court overruled its earlier decision limiting Congress' ability to regulate the "states as states." ${ }^{36}$ Citing Wechsler and Choper, the Court observed "that the composition of the Federal Government was designed in large part to protect the States from overreaching by Congress." ${ }^{37}$ The Court reasoned that "[s]tate sovereign interests . . . are more properly protected by procedural safeguards inherent in the structure of the federal system than by judicially created limitations on federal power." ${ }^{38}$ The Court's reasoning - if not its actual practice-suggests that courts should no longer review federal statutes to determine if they fall within the scope of federal power. ${ }^{39}$

\footnotetext{
${ }^{32}$ Today, one might argue that state officials are as dependent on national political parties as federal officials are on state parties.

${ }^{33} I d$. at 242.

${ }^{34}$ Id. at 243. Like Professor Choper, Professor Kramer distinguishes judicial review of the scope of federal powers from judicial review to enforce the Bill of Rights. In his view, "[t]he Framers of the Constitution expected, and may even have hoped, that judges would be active in reviewing the constitutionality of" federal statutes alleged to violate the Bill of Rights. Id. at 287-88. See also Kramer, We the Court, supra note 4, at 125 (stating that "while the Founders believed that the provisions delegating powers were not proper subjects for judicial involvement, many of them thought otherwise when it came to the rights-bearing provisions").

${ }^{35}$ Garcia v. San Antonio Metro. Transit Auth., 469 U.S. 528 (1985).

${ }^{36}$ National League of Cities v. Usery, 426 U.S. 833 (1976).

${ }^{37}$ Garcia, 469 U.S. at 550-51.

${ }^{38} I d$. at 552. Of course, Garcia's reliance on the political safeguards of federalism is subject to the same criticisms leveled at Professors Wechsler and Choper. See Vikram David Amar, Some Questions and Answers Concerning Justice Blackmun in Federalism and Separation of Powers Cases, 26 HASTINGS CONST. L.Q. 153, 155 (1998) (concluding that "of the four most important structural safeguards Justice Blackmun cited, one is pretty trivial, one never existed, and two have ceased to meaningfully exist by 1985") (citations omitted). Taken at face value, therefore, "Garcia represents a puzzling abdication of judicial responsibility." Richard H. Fallon, Jr., The Ideologies of Federal Courts Law, 74 VA. L. REV. 1141, 1247 (1988); see also id. ("Sensible judicial federalism almost always requires line-drawing between state and federal interests. This being so, there is no more justification for judicial abandonment of that role here than there would be elsewhere.").

${ }^{39}$ A careful reading of Garcia reveals that the Court's embrace of the political safeguards approach was
} 
Although the Supreme Court has not relied on the political safeguards approach since Garcia, four current members of the Court appear to support that approach. Recent decisions invalidating federal statutes on the ground that they exceed Congress' enumerated powers have provoked strong dissents urging greater reliance on the political safeguards of federalism. In United States v. Morrison, ${ }^{40}$ for example, four Justices invoked the political safeguards to support broad judicial deference to a federal statute enacted under the Commerce Clause. ${ }^{41}$ Citing Garcia, Justice Souter's dissent (joined by Justices Stevens, Ginsburg, and Breyer) stressed "the importance of national politics in protecting the States' interests," 42 and concluded that "the Constitution remits [conflicts of sovereign political interests] to politics." ${ }^{43}$ Similarly, Justice Breyer's dissent (joined by Justices Stevens, Souter, and Ginsburg) cited Professor Kramer's work to support the proposition that "Congress, not the courts, must remain primarily responsible for striking the appropriate state/federal balance." ${ }^{44}$

largely illusory. At the outset of its opinion, the Court itself reviewed the scope of Congress' power under the Commerce Clause, and concluded that if the local transit system were "a privately owned and operated enterprise, it could not credibly argue that Congress exceeded the bounds of its Commerce Clause powers." Garcia, 469 U.S. at 537. The primary issue before the Court, therefore, was whether the transit authority's "status as a [state] entity" gave rise to a special "constitutional exemption" from federal power. Id. The Court did not evade this question, but proceeded to answer it. On the merits, the Court upheld the statute, finding no constitutional "limitations on federal power." Id. at 552. It was in this context that the Court instructed states to look to the "procedural safeguards inherent in the structure of the federal system" for additional protection. Id. In short, Garcia did not invoke the political safeguards of federalism as a substitute for-but rather as a supplement to-judicial review. See Jesse H. Choper, Federalism and Judicial Review: An Update, 21 HASTINGS CONST. L.Q. 577, 579 (1994) ("The reach of the [Garcia] Court's doctrine . . . was specifically confined to national regulation of the 'States as States'; it clearly did not apply . . . to federal regulation of private persons or activities within the states."). Subsequent cases support this reading of Garcia. See United States v. Morrison, 529 U.S. 598, 617-18 (2000) (invalidating a federal statute under the Commerce Clause); United States v. Lopez, 514 U.S. 549 (1995) (same).

${ }^{40}$ U.S. v. Morrison, 529 U.S. 598 (2000).

${ }^{41}$ See Henry Paul Monaghan, A Legal Giant Is Dead, 100 COLUM. L. REV. 1370, 1372 (2000) (noting that the political safeguards approach "has always resonated in our constitutional jurisprudence, and most recently, it played a significant role in the opinions of the four dissenting justices in United States v. Morrison"). See also Kimel v. Fla. Bd. of Regents, 528 U.S. 62, 96 (2000) (Stevens, J., dissenting in part and concurring in part) (joined by Justices Souter, Ginsburg, and Breyer) (stating that "once Congress has made its policy choice, the sovereignty concerns of the several States are satisfied, and the federal interest in evenhanded enforcement of federal law, explicitly endorsed in Article VI of the Constitution, does not countenance further limitations").

${ }^{42}$ Morrison, 529 U.S. at 648 (Souter, J., dissenting).

${ }^{43} I d$. at 649 (Souter, J., dissenting). On the other hand, Justice Souter insisted in a footnote that "[p]olitics has legitimate authority . . . only within the legitimate compass of the commerce power," id. at 652 n.19 (Souter, J., dissenting), but he defined that power so broadly in light of modern economic conditions that virtually every "choice to legislate nationally" would "be a political choice and only a political choice," id.

${ }^{44} I d$. at 660 (Breyer, J., dissenting). Notwithstanding Justice Breyer's apparent approval of Professor 
Like their academic counterparts, the Morrison dissenters would sharply distinguish between judicial review of state and federal law under the Supremacy Clause. In Crosby v. National Foreign Trade Council, ${ }^{45}$ for example, the Court unanimously voted to invalidate a Massachusetts law barring state entities from purchasing goods and services from companies doing business with Burma. Justice Souter's opinion on behalf of the Court reasoned that "[b]ecause the state Act's provisions conflict with Congress' specific [statutory scheme,] . . it is preempted, and its application is unconstitutional, under the Supremacy Clause." ${ }^{46}$ Thus, the Morrison dissenters freely invoke the Supremacy Clause to invalidate state laws alleged to interfere with federal prerogatives, but apparently see little or no role for the Clause in reviewing federal statutes alleged to exceed the scope of federal powers.

\section{The Conditional Nature of the Supremacy Clause}

Relying on the political safeguards of federalism to restrict judicial review of federal statutes overlooks the conditional nature of the Supremacy Clause. Contrary to modern assumptions, the Clause does not allow courts to separate judicial review of state law from judicial review of contrary state law. Rather, whenever federal statutes conflicts with a federal statute, the Clause makes judicial review of state law contingent on judicial review of the federal statute itself. Specifically, the Clause recognizes only three sources of law as "the supreme Law of the Land": the "Constitution," "Laws," and "Treaties" of the United States. Not every federal "Law," however, qualifies under the Clause. Rather, the Clause encompasses only "the Laws of the United States which shall be made in Pursuance" of the Constitution. Although not generally recognized today for its dual purpose, the Clause pursues two distinct goals simultaneously: to secure the supremacy of federal law and to prevent Congress from exceeding the scope of its enumerated powers. As discussed below, the text, history, and structure of the Constitution all tend to confirm that the Supremacy Clause enlists courts to police the bounds of federal power in the course of upholding "the supreme Law of the Land."

Kramer's thesis, it is possible to read the dissent as undertaking judicial review and concluding on the merits that Congress' commerce power is essentially unlimited. In either case, Justice Breyer's dissent represents something of a departure from his approach just five years earlier in United States v. Lopez, 514 U.S. 549 (1995). There, Breyer made no mention of the political safeguards of federalism, and declared that "we must judge the matter independently." Id. at 624 (Breyer, J., dissenting). In addition, Justice Breyer seemed to embrace the idea of judicially enforceable limits on federal power. Thus, he steadfastly maintained that "[t]o hold this statute constitutional is not to ... hold that the Commerce Clause permits the Federal Government" to regulate any local activity. Id. In Morrison, by contrast, Justice Breyer stressed that scientific, technological, commercial, and economic "changes, taken together, mean that virtually every kind of activity, no matter how local, genuinely can affect commerce." Morrison, 529 U.S. at 660 (Breyer, J., dissenting). According to Justice Breyer, "that fact makes it close to impossible for courts to develop meaningful subject-matter categories that would exclude some kinds of local activities from ordinary Commerce Clause ‘aggregation' rules." Id.

${ }^{45}$ Crosby v. Nat'l Foreign Trade Council, 530 U.S. 363 (2000).

${ }^{46}$ Id. at 388. 


\section{A. Text}

Commentators generally overlook the Supremacy Clause as a textual basis for judicial review of federal statutes alleged to exceed Congress' enumerated powers. Rather, they generally assume that the Clause is concerned solely with judicial review of state law alleged to conflict with the "Constitution," "Laws," and "Treaties" of the United States. ${ }^{47}$ Even those who support judicial review of federal statutes typically locate such power in the structure and history of the Constitution rather than a specific provision of the constitutional text. Professors Prakash and Yoo, for example, ground judicial review in "the concept of a limited, written Constitution and the existence of a judiciary."48 Others invoke the "original intent," without tying such intent to the actual text adopted by the Founders. For instance, an influential casebook supports judicial review by observing that "[t]he existence of a judicial safeguard against unconstitutional federal laws was ... recognized on both sides in the debates over the proposal for a council of revision of acts of the national legislature." ${ }^{49}$ One need not rely on structure and history alone, however, to support judicial review of the scope of federal power. Upon examination, the Supremacy Clause appears to constitute an express textual basis for such review.

The first half of the Supremacy Clause provides that "[t]his Constitution, and the Laws of the United States which shall be made in Pursuance thereof; and all Treaties made, or which shall be made, under the Authority of the United States, shall be the supreme Law of the Land." ${ }^{50}$ Although the Clause does not explicitly tie the supremacy of "Treaties" to their constitutionality, the Clause conditions the supremacy of federal "Laws" on their being "made in Pursuance" of the Constitution. $^{51}$ By its terms, therefore, the Supremacy Clause suggests that courts should prefer federal statutes to contrary state law only if the statutes themselves fall within the scope of Congress' enumerated powers.

\footnotetext{
${ }^{47}$ See supra notes 11-19 and accompanying text.

${ }^{48}$ Prakash \& Yoo, Puzzling Persistence, supra note 25, at 1505. More recently, Professors Prakash and Yoo have explained that the text of the Supremacy Clause supports the idea that the courts must refuse to enforce federal legislation that is at odds with the Constitution. See Prakash \& Yoo, Origins of Judicial Review, supra note 25.

${ }^{49}$ Richard H. FALlON, JR. ET AL., HART \& WEChSLER'S THE FEDERAL COURTS AND tHE FEDERAL SYSTEM 12 (4th ed. 1996).

${ }^{50}$ U.S. CONST. art. VI, cl. 2 (emphasis added).

${ }^{51}$ See Missouri v. Holland, 252 U.S. 416, 433 (1920) ("Acts of Congress are the supreme law of the land only when made in pursuance of the Constitution, while treaties are declared to be so when made under the authority of the United States."). Scholars continue to debate the extent to which the federal government may adopt treaties that either exceed the scope of Congress' enumerated powers or otherwise violate the Constitution. See Curtis A. Bradley, The Treaty Power and American Federalism, 97 MicH. L. REV. 390 (1998) (criticizing the "nationalist view" of the treaty power); David M. Golove, Treaty-Making and the Nation: The Historical Foundations of the Nationalist Conception of the Treaty Power, 98 MiCH. L. REV. 1075 (2000) (defending the "nationalist view" of the treaty power); Curtis A. Bradley, The Treaty Power and American Federalism, Part II, 99 MICH. L. REV. 98 (2000) (critiquing Professor Golove's analysis).
} 
Under the Constitution, the states retain general legislative competence to regulate persons and property within their respective territories. At the same time, the Constitution delegates specific powers to the federal government to regulate matters of national concern. The nature of enumerated powers suggests that the states retain exclusive authority to govern at least some inherently local activities. Conversely, the Constitution gives the federal government exclusive power to regulate certain matters, most notably those relating to foreign relations, war, and peace. ${ }^{52}$ Generally speaking, however, "with respect to a broad array of matters, the Constitution recognizes overlapping state and federal sovereignty to establish governing rules of decision." 53 The Founders recognized that such concurrent authority would inevitably give rise to conflicts between state and federal law. The Supremacy Clause establishes a basis for resolving such conflicts by designating certain categories of federal law as "the supreme Law of the Land." Thus, in order to decide whether to apply a particular federal statute in lieu of contrary state law, a court must first determine whether the statute in question qualifies as "the supreme Law of the Land"-that is, whether the statute was "made in Pursuance" of the Constitution.

At a minimum, therefore, the Supremacy Clause appears to authorize courts to review the constitutionality of federal statutes as part of the process of resolving conflicts between such statutes and positive state law. ${ }^{54}$ The Clause, however, may authorize judicial review of federal statutes in other circumstances as well. Arguably, any federal statute that alters common law rights and duties applicable in a state is capable of triggering judicial review under the Supremacy Clause. According to Erie R.R. Co. v. Tompkins, ${ }^{55}$ "whether the law of the State shall be declared by its Legislature in a statute or by its highest court in a decision is not a matter of federal concern." ${ }^{56}$ As far as federal courts are concerned, both sources of state law supply "the law to be applied in any case," ${ }^{57}$ unless and until preempted by "the supreme Law of the Land." Thus, a court arguably has no warrant to disregard even the most trivial common law right in favor of a federal statute unless it first rejects any suggestion that the statute itself was not "made in Pursuance" of the Constitution.

Determining the precise reach of the Supremacy Clause is beyond the scope of this paper. There is at least some evidence, however, that the Founders-like their English counterpartsviewed the common law as a complete system designed to govern all aspects of human conduct,

\footnotetext{
${ }^{52}$ See U.S. CONST. art. I, §§ 8, 10; Bradford R. Clark, Federal Common Law: A Structural Reinterpretation, 144 U. PA. L. REV. 1245, 1296 (1996) ("By simultaneously granting authority to the political branches and denying power to the states, the Constitution appears to vest exclusive and plenary control over foreign relations in the federal government.") [hereinafter Clark, Federal Common Law].

${ }^{53}$ Clark, Federal Common Law, supra note 52, at 1267.

${ }^{54}$ See Prakash \& Yoo, Puzzling Persistence, supra note 25, at 1522 (concluding that "sometimes deciding the constitutionality of state legislation that conflicts with federal legislation necessarily involves judicial review of both species of legislation").

${ }^{55}$ Erie R.R. Co. v. Tompkins, 304 U.S. 64 (1938).

${ }^{56} I d$. at 78.

${ }^{57}$ Id.
} 
either through positive rules or the absence thereof. ${ }^{58}$ On that assumption, the Supremacy Clause arguably authorizes judicial review of virtually every federal statute challenged by the parties. ${ }^{59}$ As Henry Hart explained, because state courts of general jurisdiction have authority "over all persons and matters within the state's power," 60 "they have at their command a theoretically complete set of answers for every claim of breach of private duty that might be brought before them." ${ }^{61}$ Because states possess general police power, they remain free to recognize governing rules either through legislation or by judicial decision. Thus, whenever a court is asked to apply a federal statute that contradicts state statutory or common law rules of decision, the Supremacy Clause authorizes the court to determine whether the federal statute was "made in Pursuance" of the Constitution. If so, the statute constitutes "the supreme Law of the Land," and displaces contrary state law. If not, the statute binds neither state nor federal courts under the Supremacy Clause. ${ }^{62}$

The second half of the Supremacy Clause provides additional support for judicial review of federal statutes alleged to exceed the scope of Congress' enumerated powers. After defining "the supreme Law of the Land," the Clause directs that "the Judges in every State shall be bound thereby, any Thing in the Constitution or Laws of any State to the Contrary notwithstanding." 63 In so doing, the Clause "impressed state judges into national service, obliging them not only to subordinate their own state law obligations to federal ones, but also actively to police state law and void any (even the most fundamental) if it was inconsistent with any (even the least important) federal law."64 ${ }^{\text {In order }}$

\footnotetext{
${ }^{58}$ See 9 ANNALS OF CONG. 3012 (1799) (statement of Mr. Nicholas) (describing the common law of England as "a complete system for the management of all the affairs of a country").

${ }^{59}$ Cf. Bradford R. Clark, Ascertaining the Laws of the Several States: Positivism and Judicial Federalism after Erie, 145 U. PA. L. REV. 1459, 1504 (1997) (explaining that a federal court's erroneous prediction that a state's highest court would adopt a novel cause of action alters the legal rights and obligations of the parties before the court).

${ }^{60}$ Henry M. Hart, Jr., The Relations Between State and Federal Law, 54 COLUM. L. REV. 489, 492 (1954).

${ }^{61} I d$.

${ }^{62}$ Marbury v. Madison, 5 U.S. (1 Cranch) 137 (1803), arguably supports an even broader conception of judicial review under the Supremacy Clause. See infra notes 239-40 and accompanying text; see also Printz v. United States, 521 U.S. 898, 900 (1997) (stating that the Supremacy Clause "makes 'Law of the Land' only 'Laws of the United States which shall be made in Pursuance [of the Constitution]"') (quoting U.S. ConST. art. IV, cl. 2); United States v. Lopez, 514 U.S. 549 (1995) (reviewing the constitutionality of a federal statute banning handgun possession near schools notwithstanding the lack of a contrary state statute authorizing such conduct).
}

${ }^{63}$ U.S. CONST. art. VI, cl. 2. Caleb Nelson has recently examined this portion of the Supremacy Clause, and concluded that the relevant language constitutes a "non obstante" clause, a provision used to overcome the traditional rule that "repeals by implication in the law are not favored." Caleb Nelson, Preemption, 86 VA. L. REV. 225, 237-42 (2000). The result, in his view, is that the "Supremacy Clause requires preemption [of state law] only when the rules provided by state and federal law contradict each other, so that a court cannot simultaneously follow both." Id. at 303.

${ }^{64}$ James S. Liebman \& William F. Ryan, "Some Effectual Power": The Quantity and Quality of 
to comply with this command, however, state judges must identify "the supreme Law of the Land" with precision. Thus, whenever a party challenges the validity of a federal statute, state judges must determine whether the statute was "made in Pursuance" of the Constitution in order to perform their function under the Supremacy Clause.

There are several indications that federal judges were expected to review the constitutionality of federal statutes as well. Initial drafts of the Supremacy Clause designated "the legislative acts of the United States made by virtue and in pursuance of the articles of Union" as "the supreme law of the respective States" ${ }^{65}$ rather than "the supreme Law of the Land." This difference presumably reflected the preference of the original proponents of the Clause that state courts be primarily responsible for applying its commands. ${ }^{66}$ In light of the Convention's decision to authorize Congress to create lower federal courts with jurisdiction to hear cases arising under the "Constitution," "Laws," and "Treaties" of the United States, ${ }^{67}$ however, it is not surprising that the Committee of Style changed the relevant language to "the supreme Law of the Land." ${ }^{68}$ This phrase "made clear that lower federal courts - no less than state courts-would be required to apply the 'Constitution,' 'Laws,' and 'Treaties' of the United States as rules of decision, notwithstanding contrary state law." 69

Article III, read in light of the Supremacy Clause, also supports judicial review by federal courts. Although the Constitution provides that state judges "shall be bound by Oath or Affirmation to support this Constitution," ${ }^{70}$ it does not give state courts the last word on the supremacy of federal statutes. Rather, in language that closely tracks the Supremacy Clause, Article III provides that the Supreme Court shall have appellate jurisdiction in all cases "arising under this Constitution, the Laws of the United States, and Treaties made, or which shall be made, under their Authority." ${ }^{71}$ As

Decisionmaking Required of Article III Courts, 98 COLUM. L. REV. 696, 764 (1998).

${ }^{65}$ James Madison, Notes on the Constitutional Convention (July 17, 1787), in 2 THE RECORDS OF THE FEDERAL CONVENTION OF 1787 at 22 (Max Farrand ed., 1911) [hereinafter 2 FARRAND's RECORDS].

${ }^{66}$ See infra notes 77-80, 94 and accompanying text.

${ }^{67}$ U.S. CONST. art. III, § 2 .

${ }^{68}$ See Report of Committee of Style, in 2 FARRAND's RECORDS, supra note 65, at 603.

${ }^{69}$ Clark, Separation of Powers, supra note 6, at 1355 n.181.

${ }^{70}$ U.S. CONST. art. VI, cl. 3. The oath requirement alone would not have sufficed to resolve conflicts between state and federal law because state judges also take an oath to support their respective state constitutions. As Edmund Randolph recognized: "The officers of the States are already under oath to the States. To preserve a due impartiality they ought to be equally bound to the Natl. Govt." James Madison, Notes on the Constitutional Convention (June 11, 1787), in 1 THE RECORDS OF THE FEDERAL CONVENTION OF 1787 at 203 (Max Farrand ed., 1911) [hereinafter 1 FARRAND'S RECORDS]. Impartiality, of course, would not guarantee federal supremacy.

${ }^{71}$ U.S. CONST. art. III, § 2, cl. 1. See infra notes 74-75 and accompanying text. Article III, of course, gives the Supreme Court appellate jurisdiction "with such Exceptions, and under such Regulations as the Congress shall make." U.S. CONST. art. III, § 2, cl. 2. 
James Liebman and William Ryan recently observed, "the parallel language of the 'Arising Under' and Supremacy Clauses was intentional and structurally crucial." ${ }^{72}$ Thus, while the Supremacy Clause and the oath requirement obligate state judges to ascertain and enforce "the supreme Law of the Land," Article III's decision to vest appellate jurisdiction in the Supreme Court "add[s] a yet stronger (because independent, final, and effectual) external check on state judges - or, more accurately, a checking up on or spot-checking of state judicial decisions to assure that state judges are fulfilling their checking function vis-à-vis state law." ${ }^{73}$

The difference between the language of Article III and the Supremacy Clause is small, but instructive. Both parts of the Constitution refer to "the Laws of the United States," but only the Supremacy Clause adds the qualification "made in Pursuance" of this Constitution. ${ }^{74}$ This variation reflects the distinct functions that the two provisions were meant to perform. Article III merely establishes the jurisdiction of federal courts to hear cases arising under "the Laws of the United States." Jurisdiction does not depend on whether such "Laws" were "made in Pursuance" of the Constitution. Rather, it is enough to establish jurisdiction that a case arises under any federal "Law" - even an unconstitutional law. ${ }^{75}$ The Supremacy Clause, by contrast, establishes a rule of decision to be applied by courts - both state and federal-after jurisdiction attaches. Thus, Article III authorizes the Supreme Court to exercise appellate jurisdiction in every case challenging the constitutionality of a federal statute, regardless of the merits of the claim. Once jurisdiction obtains, however, the Supremacy Clause instructs the Court to decide the case by determining whether the statute was "made in Pursuance" of the Constitution.

Indeed, if the Supreme Court could not determine for itself whether a particular federal statute was "made in Pursuance" of the Constitution, then arguably the Court could not effectively perform even the basic function of ensuring that state courts comply with the Supremacy Clause. Opponents of judicial review might respond that the Court could ensure federal supremacy by simply affirming all state court decisions upholding the constitutionality of federal statutes and reversing all decisions invalidating such statutes. ${ }^{76}$ If this is what the Founders had in mind,

${ }^{72}$ Liebman \& Ryan, supra note 64, at 708.

${ }^{73} I d$. at $771-72$.

${ }^{74}$ Compare U.S. CONST. art. III, § 2, cl. 1, with U.S. CONST. art. VI, cl. 2.

${ }^{75}$ See Ableman v. Booth, 62 U.S. 506, 520 (1858) ("The judicial power covers every legislative act of Congress, whether it be made within the limits of its delegated powers, or be an assumption of power beyond the grants in the Constitution.").

${ }^{76}$ They might note that Section 25 of the Judiciary Act of 1789 restricted the Supreme Court's appellate jurisdiction over state court decisions to cases "where is drawn in question the validity of a treaty or statute of, or an authority exercised under the United States, and the decision is against their validity." Judiciary Act of $1789 \S 25,1$ Stat. 73, 85 (1789). Although the Act sought to prevent under- rather than over-enforcement of federal law, the Act left the Supreme Court free on appeal to affirm a state court decision invalidating a federal statute. A requirement of automatic reversal would have eliminated the need for the thoughtful and balanced opinions in cases like McCulloch v. Maryland, 17 U.S. (4 Wheat.) 316 (1819), and Gibbons v. Ogden, 22 U.S. (9 Wheat.) 1 (1824). Thus, although McCulloch upheld the constitutionality of the statute establishing the Bank of the United States, the Court acknowledged that 
however, then their decision to rely on state judges to strike the proper balance between state and federal law is curious at best. The Constitution authorizes - but does not require-Congress to create lower federal courts. $^{77}$ Although proponents of state power undoubtedly would have preferred to deny Congress this power, they were satisfied that state judges would retain substantial responsibility for adjudicating cases arising under federal law. ${ }^{78}$ Their calculation proved correct. Congress created inferior federal courts in 1789, but it did not give them general federal question jurisdiction until $1875,{ }^{79}$ and did not repeal the amount-in-controversy requirement until $1980 .^{80}$ Thus, the vast majority of federal question cases throughout history have been decided not by federal courts but by state courts, subject only to appellate review by the Supreme Court.

If one concludes that the Supremacy Clause authorizes both state courts and the Supreme Court to ascertain the constitutionality of federal statutes, then there is little reason to suppose that inferior federal courts lack similar authority. Such courts trace their jurisdiction in federal question cases to the same clause in Article III that authorizes the Supreme Court to exercise appellate jurisdiction in cases arising under the "Constitution," "Laws," and "Treaties" of the United States. ${ }^{81}$ In addition, as Alexander Hamilton observed, there seems to be "no impediment to the establishment of an appeal from the state courts, to the subordinate national tribunals." ${ }^{82}$ Rather, such questions

$=\mathrm{xf}$

should congress, under the pretext of executing its powers, pass laws for the accomplishment of objects not intrusted to the government; it would become the painful duty of this tribunal, should a case requiring such a decision come before it, to say, that such an act was not the law of the land.

$=\mathrm{ft}$

McCulloch, 17 U.S. at 423.

${ }^{77}$ U.S. CONST. art. I, $\S 8$, cl. 9. This power was the result of the famous Madisonian compromise at the Constitutional Convention of 1787. Some delegates favored establishing lower federal courts in the Constitution itself, while others thought such courts entirely unnecessary. To break the impasse, Madison successfully proposed giving Congress discretion to create lower federal courts. See James Madison, Notes on the Constitutional Convention (June 5, 1787), in 1 FARRAND'S RECORDS, supra note 70, at 125.

${ }^{78}$ The day after adopting the Supremacy Clause, the Convention reaffirmed Congress' power to create lower federal courts without objection. See James Madison, Notes on the Constitutional Convention (July 18, 1787), in 2 FARRAND'S RECORDS, supra note 65, at 46.

${ }^{79}$ See Act of Mar. 3, 1875, ch. 137, 18 Stat. 470 (codified as amended at 28 U.S.C. $§ 1331$ (1980)). The outgoing Federalists briefly expanded federal court jurisdiction in 1801, see Act of Feb. 13, 1801, 2 Stat. 89, but the incoming Jeffersonians promptly repealed the expansion the following year. See Act of Mar. 8, 1802, 2 Stat. 132.

${ }^{80}$ See Act of Dec. 1, 1980, 94 Stat. 2369.

${ }^{81}$ U.S. CONST. art. III, § 2. Professor Wechsler reached a similar conclusion. See infra notes 147-51 and accompanying text.

${ }^{82}$ The FeDERALIST No. 82, at 463 (Alexander Hamilton) (Clinton Rossiter ed., 1961). 
appear "to be left to the discretion of the legislature." 83 Because state courts review the constitutionality of federal statutes under the Supremacy Clause, lower federal courts exercising appellate jurisdiction would have to undertake such review as well. More fundamentally, because the Supremacy Clause requires lower federal courts to prefer "the supreme Law of the Land" to contrary state law, the Clause necessarily authorizes such courts to ascertain whether a particular federal statute was in fact "made in Pursuance" of the Constitution. ${ }^{84}$ In the end, therefore, the power to create lower federal courts merely gives Congress discretion to determine which courts will review the constitutionality of federal statutes, not whether courts will do so when called upon to decide cases in accordance with the Supremacy Clause.

\section{B. History}

History confirms that the Supremacy Clause authorizes courts to review the constitutionality of federal statutes in order to identify "the supreme Law of the Land." Delegates to the Federal Convention of 1787 widely acknowledged the need for supremacy with respect to matters properly assigned to the federal government. At the same time, delegates from small states sought ways to prevent the new government from exceeding the bounds of its enumerated powers. To further both goals, the Convention ultimately adopted the carefully worded Supremacy Clause in preference to several proposed alternatives. This choice suggests that the Founders expected the judiciary both to uphold the supremacy of federal law and to police the bounds of federal power.

The Convention recognized from the outset that some mechanism was necessary to secure the supremacy of federal law adopted under the new Constitution. ${ }^{85}$ During the Articles of Confederation, the United States in Congress operated solely through their constituent parts, and had "no power to exact obedience, or punish disobedience to their resolutions, either by pecuniary

\footnotetext{
${ }^{83} I d$.

${ }^{84}$ The Supreme Court's jurisdiction over appeals from both state and lower federal courts also supports judicial review by lower federal courts. Through its power to create lower federal courts and control their jurisdiction, Congress has substantial discretion to determine whether state or federal courts will adjudicate cases arising under federal law. In either case, the Supreme Court generally has appellate jurisdiction over such cases. It would be odd to conclude that the Supreme Court can assess the constitutionality of federal statutes in cases coming from state court, but not in cases coming from federal court. This suggests that the Supremacy Clause requires federal courts - no less than state courts - to identify and apply "the supreme Law of the Land," that is, to determine whether an applicable federal statute was "made in Pursuance" of the Constitution.

${ }^{85}$ This Article examines the notes of the Federal Convention of 1787 not because they are authoritative as to the meaning of the Constitution, but because (like The Federalist) they have "significant interpretive value as a detailed, contemporaneous exposition of the Constitution by authors who were intimately familiar with its legal and political background." John F. Manning, Textualism and the Role of The Federalist in Constitutional Adjudication, 66 GEO. WASH. L. REV. 1337, 1339 (1998). In addition, the notes establish a record of the proposals that the Convention actually considered, rejected, and adopted. For these reasons, "the recorded deliberative process that produced the texts of Article III and the Supremacy Clause is an unusually authoritative (i.e., accurate and legitimate) source of the meaning of those texts." Liebman \& Ryan, supra note 64 , at 707.
} 
mulcts, by a suspension or divestiture of privileges, or by any other constitutional means." 86 The proposed Constitution addressed these defects by providing that, within its assigned powers, "the national government would act directly on the population rather than mediately through the states." ${ }^{87}$ At the same time, the Constitution "preserved the States as separate sources of authority and organs of administration." ${ }^{88}$ The Founders understood that permitting the federal government and the states to exercise concurrent power over the same individuals in the same territory would inevitably lead to conflicts between state and federal law. ${ }^{89}$ Thus, it was essential to the success of the new Constitution to establish a mechanism capable of resolving such conflicts and upholding the supremacy of federal law within its proper sphere. ${ }^{90}$

The Founders considered three alternatives, each of which looked to a different branch of government for its implementation. ${ }^{91}$ First, the Virginia Plan initially proposed authorizing the Union to use military force to coerce the states to comply with federal law. ${ }^{92}$ Second, the Virginia Plan suggested giving the national legislature power to negative state laws. ${ }^{93}$ Third, the New Jersey Plan proposed requiring state courts (subject to federal appellate review) to enforce the Laws of the United States "made by virtue \& in pursuance of the powers hereby . . . vested in them" as "the supreme law of the respective States." ${ }^{94}$ The Founders' decision to reject the first two alternatives in

${ }^{86}$ THE FEDERALIST No. 21, at 138 (Alexander Hamilton) (Clinton Rossiter ed., 1961).

${ }^{87}$ JaCK N. RAKOVE, ORIGINAL MEANings: Politics AND IDEAS IN THE MAKING OF THE CONSTITUTION 169 (1996); see also Wechsler, supra note 3, at 543 ("Our constitution makers established a central government authorized to act directly upon individuals through its own agencies - and thus they formed a nation capable of function and growth.").

${ }^{88}$ Wechsler, supra note 3, at 543.

${ }^{89}$ See Jack N. Rakove, The Origins of Judicial Review: A Plea for New Contexts, 49 STAN. L. REV. 1031, 1042 (1997).

${ }^{90} I d$.

${ }^{91}$ For a more detailed discussion of these alternatives, see Clark, Separation of Powers, supra note 6, at 1348-55. See also RAKOVE, supra note 87, at 171-72 ("In determining how national acts could be enforced against potential opposition, the Convention could choose among three mechanisms: the use of coercive force against defiant states ... . ; the negative on state laws; or the legal prosecution of individuals who violated or interfered with national law.").

${ }^{92}$ James Madison, Notes on the Constitutional Convention (May 29, 1787), in 1 FARRAND'S RECORDS, supra note 70, at 21.

${ }^{93}$ James Madison, Notes on the Constitutional Convention (May 31, 1787), in 1 FARRAND'S RECORDS, supra note 70 , at 54 .

${ }^{94}$ James Madison, Notes on the Constitutional Convention (June 15, 1787), in 1 FARRAND's RECORDS, supra note 70, at 245. The New Jersey Plan did not authorize the creation of lower federal courts. Rather, the Plan proposed that all cases arising under federal law be adjudicated "by the Common Law Judiciarys of the State[s]" in the first instance. Id. at 243. These decisions would have been subject to appellate review by "a federal Judiciary ... to consist of a supreme Tribunal." Id. at 244. 
favor of the third has important implications for both the existence of judicial review and its role in maintaining the federal system.

As introduced, the Virginia Plan proposed both coercive force and a congressional negative. Concerning the former, the Plan would have authorized the National Legislature "to call forth the force of the Union agst. any member of the Union failing to fulfill its duty under the articles thereof." ${ }^{95}$ Although the Convention embraced many aspects of the Virginia Plan, the delegates were immediately alarmed by the proposed use of force. ${ }^{96}$ James Madison "observed that the more he reflected on the use of force, the more he doubted the practicability, the justice and the efficacy of it when applied to people collectively and not individually. A Union of the States containing such an ingredient seemed to provide for its own destruction." ${ }^{97}$ Madison "hoped that such a system would be framed as might render this recourse unnecessary." ${ }^{\prime 98}$ The Convention tabled the proposal and never seriously entertained this alternative. ${ }^{99}$

Madison preferred the second approach, which would have given Congress broad power to negative state laws. As set forth in the Virginia Plan, the proposed negative would have empowered Congress "to negative all laws passed by the several States, contravening in the opinion of the National Legislature the articles of [the] Union." ${ }^{100}$ The Convention initially approved the negative in this form. ${ }^{101}$ Mr. Pinkney subsequently attempted to expand the device by moving "that the

\footnotetext{
${ }^{95}$ James Madison, Notes on the Constitutional Convention (May 29, 1787), in 1 FARRAND'S RECORDS, supra note 70, at 21.

${ }^{96}$ See James Madison, Notes on the Constitutional Convention (May 31, 1787), in 1 FARRAND'S RECORDS, supra note 70, at 54 ("The use of force agst. a State, would look more like a declaration of war, than an infliction of punishment, and would probably be considered by the party attacked as a dissolution of all previous compacts by which it might be bound.").
}

${ }^{97} I d$. Madison's views on this question were apparently unsettled until he spoke at the Convention. See Liebman \& Ryan, supra note 64, at 710 (stating that private correspondence suggests that "Madison initially favored authorizing the federal government to use military force to bring recalcitrant states, and particularly state legislatures, into line with national law").

${ }^{98}$ James Madison, Notes on the Constitutional Convention (May 31, 1787), in 1 FARRAND'S RECORDS, supra note 70 , at 54 .

${ }^{99}$ The New Jersey Plan subsequently proposed permitting "the federal Executive . . . to call forth ye power of the Confederated States . . . to enforce and compel an obedience to . . . Acts [of Congress], or an Observance of . . . Treaties." James Madison, Notes on the Constitutional Convention (June 15, 1787), in 1 FARRAND'S RECORDS, supra note 70, at 245. The proposal again generated decisive opposition from delegates like Alexander Hamilton. See James Madison, Notes on the Constitutional Convention (June 18, 1787), in 1 FARRAND'S RECORDS, supra note 70, at 285 ("But how can this force be exerted on the States collectively. It is impossible. It amounts to a war between the parties. Foreign powers also will not be idle spectators. They will interpose, the confusion will increase, and a dissolution of the Union ensue.").

${ }^{100}$ James Madison, Notes on the Constitutional Convention (May 29, 1787), in 1 FARRAND's RECORDS, supra note 70, at 21.

${ }^{101}$ See James Madison, Notes on the Constitutional Convention (May 31, 1787), in 1 FARRAND'S RECORDS, supra note 70, at 54 (approving the negative and adding "the words 'or any Treaties subsisting under the 
National Legislature shd. have authority to negative all Laws which they shd. judge to be improper."'102 Madison seconded the motion, stating that he "regard[ed] an indefinite power to negative legislative acts of the States as absolutely necessary to a perfect system." ${ }^{103}$

The suggestion of an unlimited congressional negative provoked strong objections by delegates from small states fearful of unchecked federal power. For example, Elbridge Gerry declared that "[t]he Natl. Legislature with such a power may enslave the States. Such an idea as this will never be acceded to." ${ }^{104}$ Similarly, "Mr. Butler was vehement agst. the Negative in the proposed extent, as cutting off all hope of equal justice to the distant States. The people there would not he was sure give it a hearing." ${ }^{105}$ These objections were decisive and the Convention rejected Pinckney's proposal to expand the negative. ${ }^{106}$

The Convention subsequently rejected even the original congressional negative. Although limited on its face, the negative would have allowed Congress to determine for itself the scope of its powers vis-à-vis the states. This result was simply unacceptable to a majority of states at the Convention. $^{107}$ Thus, the day after granting the states equal suffrage in the Senate, ${ }^{108}$ the Convention reconsidered and rejected the congressional negative. ${ }^{109}$ On this occasion, delegates

authority of the Union"' to the end of the clause).

${ }^{102}$ James Madison, Notes on the Constitutional Convention (June 8, 1787), in 1 FARRAND'S RECORDS, supra note 70, at 164 .

${ }^{103} I d$

${ }^{104} I d$. at 165 .

${ }^{105} \mathrm{Id}$. at 168 .

${ }^{106}$ Id. Near the end of the Convention, several delegates attempted to revive an essentially unlimited congressional power "'[t]o negative all laws passed by the several States interfering in the opinion of the Legislature with the General interests and the harmony of the Union."' James Madison, Notes on the Constitutional Convention (Aug. 23, 1787), in 2 FARRAND'S RECORDS, supra note 65, at 390. Although this version of the negative would have required "that two thirds of the members of each House assent to" its exercise, id., opponents nevertheless objected in strong terms: "If nothing else, this alone would damn and ought to damn the Constitution. Will any State ever agree to be bound hand \& foot in this manner." Id. at 391. The Convention again rejected the congressional negative. Id.

${ }^{107}$ Consider, for example, how Congress might have used the negative to resolve the questions presented by McCulloch v. Maryland, 17 U.S. (4 Wheat.) 316 (1819). Congress enacted a law establishing the Bank of the United States. Maryland reacted by taxing the operations of the Bank and denying the existence of federal power. Id. at 317. If Congress had the negative, it could have simply invalidated the Maryland law as "contravening in the opinion of the National Legislature the articles of the Union"-specifically, the articles of the Union that authorized Congress to establish the Bank. Under the Supremacy Clause, of course, the judiciary, rather than Congress, resolves such questions. See infra notes 210-25 and accompanying text.

${ }^{108}$ See James Madison, Notes on the Constitutional Convention (July 16, 1787), in 2 FARRAND'S RECORDS, supra note 65 , at 15-16.

${ }^{109}$ See James Madison, Notes on the Constitutional Convention (July 17, 1787), in 2 FARRAND'S RECORDS, 
from small states voiced strong opposition to any congressional negative. These members considered the negative to be both unwarranted and impracticable. ${ }^{110}$ Madison attempted to defend the negative, ${ }^{111}$ but influential delegates remained unconvinced. Madison reports that "Mr. Govr. Morris was more \& more opposed to the negative. The proposal of it would disgust all the States. A law that ought to be negatived will be set aside in the Judiciary departmt. and if that security should fail; may be repealed by a Nationl. law."112 The Convention rejected "the power of negativing laws of States" by a vote of seven states to three. ${ }^{113}$

Immediately after rejecting the congressional negative, the Convention adopted the Supremacy Clause, ${ }^{114}$ "thereby delegating to judges (state and federal) what previously had been the [negative's] function of voiding state law contrary to federal law." ${ }^{115}$ The Supremacy Clause, however, did not merely reassign to courts the task of upholding the supremacy of federal law. It also required courts to police the bounds of federal power by conditioning the supremacy of federal statutes on compliance with "this Constitution." Significantly, every version of the Supremacy Clause considered by the Convention conditioned the supremacy of federal statutes on their fidelity to the Constitution. For example, as first proposed as part of the New Jersey Plan, the Clause confined "the supreme law of the respective States" to "all Acts of the U. States in Congs. made by virtue $\&$ in pursuance of the powers hereby $\&$ by the articles of confederation vested in them." ${ }^{116}$

supra note 65 , at $27-28$.

${ }^{110}$ See id. at 27 ("Mr. Sherman thought it unnecessary, as the Courts of the States would not consider as valid any law contravening the Authority of the Union, and which the legislature would wish to be negatived. Mr. L. Martin considered the power as improper \& inadmissable. Shall all the laws of the States be sent up to the Genl. Legislature before they shall be permitted to operate?").

${ }^{111}$ See id. at 28 ("A power of negativing the improper laws of the States is at once the most mild \& certain means of preserving the harmony of the system.").

${ }^{112} I d$. Liebman and Ryan suggest that Gouverneur Morris' opposition to the negative may have been caused by the Convention's decision to grant the states equal suffrage in the Senate. "With large states now vulnerable to coalitions of small states capable of vetoing their internal legislation (as well as vice versa), the national negative immediately encountered new opposition." Liebman \& Ryan, supra note 64, at 729.

${ }^{113}$ James Madison, Notes on the Constitutional Convention (July 17, 1787), in 2 FARRAND'S RECORDS, supra note 65, at 28.

${ }^{114}$ See Journal of the Constitutional Convention (July 17, 1787), in 2 FARRAND's RECORDS, supra note 65, at 22. The Convention subsequently amended the Supremacy Clause to include the "Constitution" (in addition to "Laws" and "Treaties"), James Madison, Notes on the Constitutional Convention (Aug. 23, 1787), in 2 FARRAND'S RECORDS, supra note 65, at 389, and to make clear that these three sources of federal law were not merely "the supreme law of the respective States," but "the supreme Law of the Land." Report of Committee of Style, in 2 FARRAND'S RECORDS, supra note 65, at 603.

${ }^{115}$ Liebman \& Ryan, supra note 64, at 730.

${ }^{116}$ James Madison, Notes on the Constitutional Convention (June 15, 1787), in 1 FARRAND's RECORDS, supra note 70, at 245. 
Similarly, the version adopted following rejection of the congressional negative recognized "the legislative acts of the United States made by virtue and in pursuance of the articles of Union" as "the supreme law of the respective States." ${ }^{117}$ As finally adopted, the Supremacy Clause designates "the Laws of the United States which shall be made in Pursuance" of "[t]his Constitution" as "the supreme Law of the Land." ${ }^{118}$ Thus, under every version of the Clause, state courts were required to disregard state law in favor of contrary federal statutes only if they determined that the statutes themselves were constitutional.

During the ratification debates, moreover, supporters of the proposed Constitution repeatedly stressed the conditional nature of federal supremacy in order to reassure those who feared unlimited federal power. $^{119}$ In Massachusetts, for example, Cassius defended the Supremacy Clause, "which knaves and blockheads have so often dressed up in false colours." ${ }^{120}$ After quoting the Clause in full, he explained how the Clause would actually constrain the federal government:

This is the article which they say is so arbitrary and tyrannical, that unless you have a bill of rights to secure you, you are ruined forever. But in the name of common sense I would ask, ... . would it not be much easier to resort to the federal constitution, to see if therein power is given to Congress to make the law in question. If such power is not given, the law is in fact a nullity, and the people will not be bound thereby. For let it be remembered, that such laws, and such only, as are founded on this constitution, are to be the supreme law of the land . ... 121

George Nicholas, of Virginia, made similar assurances. He stressed that the Supremacy Clause does not "in any manner give them this unlimited power, because this [Clause] only declares those laws binding which are made in pursuance of or in conformity to the particular powers given by the constitution." 122

Similarly, in Federalist 33, Alexander Hamilton defended the Supremacy Clause by emphasizing its limits:

If a number of political societies enter into a larger political society, the laws which the latter may enact, pursuant to the powers intrusted [sic] to it by its constitution,

\footnotetext{
${ }^{117}$ Journal of the Constitutional Convention (July 17, 1787), in 2 FARRAND's RECORDS, supra note 65, at
} 22.

${ }^{118}$ U.S. CONST. art. VI, cl. 2.

${ }^{119}$ See generally Prakash \& Yoo, Puzzling Persistence, supra note 25, at 1507-21 (discussing the ratification debates and the expectations regarding judicial review).

${ }^{120}$ Cassius VI, MASS. GAZETTE, Dec. 25, 1787, reprinted in 5 THE DOCUMENTARY HISTORY OF THE RATIFICATION OF THE CONSTITUTION 513 (John P. Kaminski \& Gaspare J. Saladino eds., 1998).

${ }^{121} I d$

${ }^{122}$ Letter from George Nicholas (Feb. 16, 1788), in 8 THE DOCUMENTARY HISTORY OF THE RATIFICATION OF THE CONSTITUTION 369 (John P. Kaminski \& Gaspare J. Saladino eds., 1988). 
must necessarily be supreme over those societies and the individuals of whom they are composed.... But it will not follow from this doctrine that acts of the larger society which are not pursuant to its constitutional powers, but which are invasions of the residuary authorities of the smaller societies, will become the supreme law of the land. These will be merely acts of usurpation, and will deserve to be treated as such." 123

Although he thought that such a limitation would have been implicit in any event, Hamilton stressed that the Supremacy Clause "expressly confines this supremacy to laws made pursuant to the Constitution." 124

The Founders' decision to adopt the Supremacy Clause rather than the congressional negative strongly supports judicial review to police the bounds of federal power. As Jack Rakove has explained, "federalism questions were central to the origins of judicial review" because federalism "requires mechanisms to resolve the conflicts that arise when national and state legislation overlap." ${ }^{125}$ "The decision to rely on courts-rather than Congress or the Presidentsuggests that the Founders wanted conflicts between state and federal law to be resolved by principled adjudication, rather than political will or force." ${ }^{126}$ The Founders selected the Supremacy Clause over the congressional negative primarily because the small states refused to entrust Congress with unchecked power. As initially approved, the negative would have empowered Congress "to negative all laws passed by the several States, contravening in the opinion of the National Legislature the articles of the Union." ${ }^{127}$ By leaving this determination to Congress, the negative would have effectively vested Congress with plenary power to suspend state law. ${ }^{128}$ For

${ }^{123}$ The FedERALIST No. 33, at 204 (Alexander Hamilton) (Clinton Rossiter ed., 1961); see also THE FEDERALIST No. 27, at 177 (Alexander Hamilton) (Clinton Rossiter ed., 1961) (noting "that the laws of the Confederacy, as to the enumerated and legitimate objects of its jurisdiction, will become the SUPREME LAW of the land").

${ }^{124}$ THE FEDERALIST NO. 33, at 205 (Alexander Hamilton) (Clinton Rossiter ed., 1961). The example Hamilton gave- - conflict between a state tax law and a federal statute prohibiting the tax-confirms that he understood the Clause to authorize courts to disregard unconstitutional federal statutes in favor of contrary state law. See id. ("Though a law, therefore, for laying a tax for the use of the United States would be supreme in its nature and could not legally be opposed or controlled, yet a law for abrogating or preventing the collection of a tax laid by the authority of a State (unless upon imports and exports) would not be the supreme law of the land, but a usurpation of power not granted by the Constitution.").

${ }^{125}$ Rakove, supra note 89, at 1042.

${ }^{126}$ Clark, Separation of Powers, supra note 6, at 1348; see Jonathan T. Molot, The Judicial Perspective in the Administrative State: Reconciling Modern Doctrines of Deference with the Judiciary's Structural Role, 53 STAN. L. REV. 1, 12-41 (2000).

${ }^{127}$ James Madison, Notes on the Constitutional Convention (May 29, 1787), in 1 FARRAND'S RECORDS, supra note 70, at 21 (emphasis added).

${ }^{128}$ See Prakash \& Yoo, Puzzling Persistence, supra note 25, at 1503 (stating that "in the absence of judicial review of federal laws, Congress would, in effect, have the unchecked power to veto state legislation"). 
this reason, the Convention rejected the negative and adopted the mechanism favored by proponents of state power: the Supremacy Clause. Unlike the negative, the Supremacy Clause assigned resolution of federal-state conflicts to courts (both state and federal). Thus, modern suggestions that the Founders meant to deny courts power to review the constitutionality of federal statutes contradict the historical record, and would effectively nullify the Founders' decision to adopt the Supremacy Clause instead of the congressional negative.

\section{Structure}

Several aspects of the constitutional structure reinforce the conclusion that the Supremacy Clause authorizes courts to police the bounds of federal power in the course of identifying "the supreme Law of the Land." First, this reading of the Clause upholds constitutional federalism because it furthers the principle that the powers not delegated to the federal government are reserved to the states or to the people. Second, judicial review under the Supremacy Clause reinforces the constitutional separation of powers because it prevents Congress from authoritatively judging the scope of its own powers. Third, judicial review is necessary to respect the written Constitution and Article V's procedures for adopting constitutional amendments. Abandoning judicial review to inquire whether federal statutes were "made in Pursuance" of the Constitution would undermine each of these essential features of the constitutional structure.

First, the Founders understood the Constitution to assign limited powers to the federal government and to leave the remainder with the states and the people. As James Madison explained: "The powers delegated by the proposed Constitution to the federal government are few and defined. Those which are to remain in the state governments are numerous and indefinite." ${ }^{129}$ The Supremacy Clause helps to maintain this constitutional division of power by requiring courts to disregard state law in favor of federal statutes only if the latter were "made in Pursuance" of the Constitution. For this reason, the "judicial power was justly regarded as indispensable, not merely to maintain the supremacy of the laws of the United States, but also to guard the States from any encroachment upon their reserved rights by the General Government." ${ }^{130}$

Permitting Congress to exceed the scope of its enumerated powers with impunity would threaten the constitutional division of power between the federal government and the states. Indeed, denying judicial review of federal statutes under the Supremacy Clause would effectively give Congress greater power than the proposed congressional negative. The negative would have merely allowed Congress to suspend state laws; it conferred no congressional power to transform federal commands into supreme law binding throughout the nation. ${ }^{131}$ By contrast, permitting Congress to

${ }^{129}$ The FEDERALIST No. 45, at 260 (James Madison) (Clinton Rossiter ed., 1961); see also U.S. CONST. amend. X.

${ }^{130}$ Ableman v. Booth, 62 U.S. 506, 520 (1858).

${ }^{131}$ One difference between Professor Kramer's interpretation of the Supremacy Clause and the congressional negative is that state law would remain in effect until invalidated by a court, whereas the negative contemplated that states would submit their laws to Congress before they took effect. The practical problems raised by this feature of the negative undoubtedly contributed to its rejection. See RAKOVE, supra note 87, at 174 ("These unanswerable objections - so powerful because they were also so pragmaticexposed the underlying defects in the negative that Madison never resolved."). 
exercise legislative power unchecked by judicial review would give Congress complete discretion to replace state law with affirmative federal law of its choosing. This would transform the Supremacy Clause from a provision designed to keep the states and the federal government within their proper spheres into a means of enforcing unlimited federal power.

Second, by enlisting courts - both state and federal - to uphold the limits of federal power, the Founders established an important check against the excessive accumulation of power by a single branch of government. The congressional negative-initially embraced but ultimately rejected by the Convention-would have allowed Congress to judge the scope of its own powers vis-à-vis the states and the people. ${ }^{132}$ The Founders undoubtedly preferred the Supremacy Clause in part because of the widely held view that no one should be the judge in his own cause. ${ }^{133}$ Reassigning resolution of conflicts between state and federal law from Congress to the courts thus reinforced an important aspect of the constitutional separation of powers.

Both state and federal courts enjoy significant independence from Congress. State courts are creatures of state law and are thus generally insulated from congressional coercion or control. Similarly, by design, federal judges enjoy substantial independence from the political branches by virtue of the constitutional guarantees of life tenure and salary protection. ${ }^{134}$ The structural independence of the judiciary suggests that the Supremacy Clause was designed to keep both the federal government and the states within their constitutionally defined spheres. As James Wilson explained during the ratification debates:

If a law should be made inconsistent with those powers vested by this instrument in Congress, the judges, as a consequence of their independence, and the particular powers of government being defined, will declare such law to be null and void. For the power of the Constitution predominates. Anything, therefore, that shall be enacted by Congress contrary thereto will not have the force of law. ${ }^{135}$

${ }^{132}$ See supra notes $100-13$ and accompanying text.

${ }^{133}$ See Jonathan T. Molot, Reexamining Marbury in the Administrative State: A Structural and Institutional Defense of Judicial Power over Statutory Interpretation, 96 Nw. U. L. REV. 1239, 1283 (2002) ("Believing that no one ought to be 'judge in his own cause,' the Founders established three separate branches of government and positioned the judiciary to keep the political branches within the bounds of their lawful authority."); John F. Manning, Constitutional Structure and Judicial Deference to Agency Interpretations of Agency Rules, 96 ColuM. L. REV. 612, 646 (1996) (explaining that the constitutional "separation of lawmaking from law-exposition promoted the rule of law and controlled arbitrary government"); Philip A. Hamburger, Revolution and Judicial Review: Chief Justice Holt's Opinion in City of London v. Wood, 94 COLUM. L. REV. 2091 (1994) (linking this maxim to judicial review in early eighteenth century England); Paul R. Verkuil, Separation of Powers, the Rule of Law and the Idea of Independence, 30 WM. \& MARY L. REV. 301, 305 (1989) (stating that "the notion that no man can be a judge in his own cause was among the earliest expressions of the rule of law in Anglo-American jurisprudence"); $c f$. THE FEDERALIST NO. 80, at 446 (Alexander Hamilton) (Clinton Rossiter ed., 1961) (defending federal jurisdiction over disputes between two states on the ground that "[n]o man ought certainly to be a judge in his own cause, or in any cause in respect to which he has the least interest or bias").

\footnotetext{
${ }^{134}$ U.S. CONST. art. III, § 1.

${ }^{135}$ Debates of the Pennsylvania Convention (Dec. 7, 1787), in 2 THE DOCUMENTARY HISTORY OF THE
} 
Denying courts the power to review the constitutionality of federal statutes under the Supremacy Clause would undermine this important structural check and effectively reverse the Founders' decision to adopt the Supremacy Clause instead of the congressional negative.

Third, by confining the supremacy of federal statutes to those "made in Pursuance" of "[t]his Constitution," the Supremacy Clause upholds the written Constitution as the highest form of federal law. ${ }^{136}$ In the absence of such qualifying language, the "Laws of the United States" and the "Constitution" arguably could have claimed equal status as "the supreme Law of the Land," leaving courts without clear guidance in the event of a conflict. Thus, interpreting the Supremacy Clause to authorize judicial review of federal statutes reinforces the distinctive character of the American Constitution as fundamental law of the highest order. ${ }^{137}$

Similarly, if all "Laws" enacted by Congress qualified as "the supreme Law of the Land," then Congress and the President could effectively amend the Constitution by ordinary legislation. This would contradict the spirit, if not the letter, of Article V, which establishes precise procedures to govern constitutional amendments. ${ }^{138}$ As Henry Monaghan has explained, "Article V was designed to permit a very small number of states (currently thirteen) containing but a fraction of the total national population to block constitutional change." ${ }^{139}$ Allowing Congress and the President to alter the Constitution by ordinary legislation — unchecked by judicial review-would circumvent Article V's carefully crafted procedures. ${ }^{140}$ Justice Harlan made this point explicitly in Oregon $v$.

RATIFICATION OF THE CONSTITUTION 517 (Merrill Jensen ed., 1976).

${ }^{136}$ See Prakash \& Yoo, Puzzling Persistence, supra note 25, at 1503 (stating that "like judicial review generally, judicial review of state legislation was simply understood to follow from the nature of a written limited Constitution").

${ }^{137}$ See Gordon S. WoOd, THE CREATION OF THE AMERICAN REPUBLIC: 1776-1787, at 259-61 (1969) (contrasting "the Americans' peculiar conception of a constitution" with the inability of eighteenth-century Englishmen to "conceive of the constitution as anything anterior and superior to government and ordinary law"); Gordon S. Wood, The Origins of Judicial Review Revisited, or How the Marshall Court Made More Out of Less, 56 WASH. \& LEE L. REV. 787, 793 (1999) (suggesting that judicial review flowed "from fundamental changes taking place in the Americans' ideas of government and law" during the 1780s and 1790s).

${ }^{138}$ See John Harrison, The Constitutional Origins and Implications of Judicial Review, 84 VA. L. REV. 333, 348 (1998); see also Prakash \& Yoo, Puzzling Persistence, supra note 25, at 1470 ("We doubt that the Constitution permits Congress to effectively amend the Constitution outside Article V's cumbersome procedure. Yet this would be the practical result in a world without judicial review.").

${ }^{139}$ Henry Paul Monaghan, We the People[s], Original Understanding, and Constitutional Amendment, 96 COLUM. L. REV. 121, 125 (1996).

${ }^{140}$ See Clark, Separation of Powers, supra note 6, at 1331 ("Both the specificity of, and the purposeful variations among, the procedures prescribed by the Constitution for adopting the 'Constitution,' 'Laws,' and 'Treaties' suggest exclusivity."). 
Mitchell: ${ }^{141}$

In Article $\mathrm{V}$, the Framers expressed the view that the political restraints on Congress alone were an insufficient control over the process of constitution making. The concurrence of two-thirds of each House and of three-fourths of the States was needed for the political check to be adequate. To allow a simple majority of Congress to have final say on matters of constitutional interpretation is therefore fundamentally out of keeping with the constitutional structure. ${ }^{142}$

For these reasons, the text, history, and structure of the Constitution support judicial review of federal statutes to police the constitutional limits of federal power.

\section{Counterarguments}

Some opponents of judicial review do not merely contest its availability to invalidate statutes that exceed the scope of Congress' enumerated powers. Rather, they argue more broadly that courts lack clear constitutional authority to set aside any federal statute, at least if enacted in accordance with the procedures set forth in Article I, Section 7. The Supremacy Clause undercuts these claims as well.

In 1958, for example, Learned Hand famously declared that "[t]here was nothing in the United States Constitution that gave courts any authority to review the decisions of Congress." ${ }^{143}$ In addition, he specifically denied that "any support for the doctrine of the supremacy of the judiciary [can] be found in the 'Supremacy Clause."'144 In his view, "the clause was obviously directed against the states alone to prevent their intruding upon the powers they had delegated or failing to obey limitations on their own powers that they had accepted." ${ }^{145}$ Hand's conclusion, however, is curious in light of his willingness to admit arguendo "that when a conflict is between a federal law and a state law or constitution, the state court is to determine the validity of the federal law quoad the federal constitution," and "that on some occasions the Supreme Court might have to decide whether a state court's construction of the Constitution was correct." 146

Interestingly, it was Herbert Wechsler who refuted Judge Hand's assertions the following year. Without discussing the political safeguards of federalism, Professor Wechsler stated that he had "not the slightest doubt regarding the legitimacy of judicial review, whether the action called in

\footnotetext{
${ }^{141}$ Oregon v. Mitchell, 400 U.S. 112 (1970).

${ }^{142}$ Id. at 205 (Harlan, J., concurring in part and dissenting in part).

${ }^{143}$ LEARNED HAND, THE BILL OF RIGHTS 10 (1958).

${ }^{144} I d$. at 5.

${ }^{145} I d$.

${ }^{146} I d$.
} 
question ... is legislative or executive, federal or state. ${ }^{147}$ Wechsler quoted the Supremacy Clause in full and explained that judicial review "is grounded in the language of the Constitution and is not a mere interpolation." ${ }^{148}$ Wechsler declined to read the Supremacy Clause merely "as a grant of jurisdiction to state courts, implying a denial of the power and duty to all others." ${ }^{149}$ Rather, he interpreted Article III to mean "that if a state court passes on a constitutional issue, as the supremacy clause provides that it should, its judgment is reviewable, subject to congressional exceptions, by the Supreme Court, in which event that court must have no less authority and duty to accord priority to constitutional provisions than the court that it reviews." ${ }^{150}$ In this circumstance, Wechsler did not think it possible to conclude

that if Congress opts, as it has opted, to create a set of lower courts, those courts in cases falling within their respective jurisdictions and the Supreme Court when it passes on their judgments are less or differently constrained by the supremacy clause than are the state courts, and the Supreme Court when it reviews their judgments. ${ }^{151}$

Alexander Bickel advanced a more textually grounded objection to judicial review. He narrowly construed the Supremacy Clause and concluded that the "authority to determine the meaning and application of a written constitution is nowhere defined or even mentioned in the document itself." ${ }^{152}$ In Professor Bickel's view, the phrase "Laws ... made in Pursuance" of the Constitution refers solely to the procedural constraints set forth in Article I, Section 7:

[I]t fully meets all else that is compelling in the language of the clause simply to conclude that the proviso that only those federal statutes are to be supreme which are made in pursuance of the Constitution means that the statutes must carry the outer indicia of validity lent them by enactment in accordance with the constitutional forms. If so enacted, a federal statute is constitutional. ${ }^{153}$

${ }^{147}$ Herbert Wechsler, Toward Neutral Principles of Constitutional Law, 73 HARV. L. REV. 1, 2 (1959).

${ }^{148} I d$. at 3.

${ }^{149} I d$.

${ }^{150} I d$. at 4.

${ }^{151}$ Id. at $4-5$.

${ }^{152}$ AleXANDER M. BiCKel, The LeAst DANGerous Branch: THE Supreme COURT AT THE BAR OF POLITICS 1 (2d ed. 1986).

${ }^{153}$ Id. at 9; see also William Van Alstyne, A Critical Guide to Marbury v. Madison, 1969 DUKE L.J. 1, 20 ("The phrase 'in pursuance thereof' might as easily mean `in the manner prescribed by this Constitution,' in which case acts of Congress might be judicially reviewable as to their procedural integrity, but not as to their substance."); Harrison, supra note 138, at 346 n.48 ("At the least, that phrase alludes to the Article I, § 7 process, so that the clause applies only to those writings that have been duly adopted."). 
If Bickel is correct, then all courts - whether state or federal, trial or appellate-must simply accept properly enacted federal statutes as "the supreme Law of the Land" without inquiring into their constitutionality.

The Supremacy Clause undoubtedly incorporates the procedural safeguards that Professor Bickel invoked. ${ }^{154}$ But the text in question is not so limited, and the history of the Clause contradicts Bickel's interpretation. As discussed, the New Jersey Plan originally referred to "all Acts of the U. States in Congs. made by virtue \& in pursuance of the powers hereby \& by the articles of confederation vested in them."155 Federal statutes not made "in pursuance of" such "powers," therefore, would not qualify as "the supreme law of the respective States."156 All subsequent versions of the Clause contained similar language conditioning the supremacy of federal statutes on their constitutionality. ${ }^{157}$ As reported by the Committee of Detail, for example, the Clause restricted supremacy to the "Acts of the Legislature of the United States made in Pursuance of this Constitution." ${ }^{158}$ Similarly, as adopted, the Clause refers to "This Constitution, and the Laws of the United States which shall be made in Pursuance thereof." ${ }^{159}$

On its face, this language is not limited to federal statutes enacted pursuant to federal lawmaking procedures. First, the term "Laws," by itself, refers to federal statutes adopted according to Article I, Section 7. That section provides that every bill "shall, before it becomes a Law," be

\footnotetext{
${ }^{154}$ See Clark, Separation of Powers, supra note 6, at 1338 (explaining that the Supremacy Clause necessarily "incorporates several significant protections of state authority found elsewhere in the Constitution" by recognizing only the "Constitution," "Laws," and "Treaties" of the United States as "the supreme Law of the Land"); see also Ernest A. Young, Two Cheers for Process Federalism, 46 VILL. L. REV. 1349, 1364-65 (2001) (stating that process federalism protects state authority). Federal lawmaking procedures "safeguard federalism both by making 'the supreme Law of the Land' more difficult to adopt and by requiring the participation and assent of actors originally subject to varying degrees of state influence and control." Clark, Separation of Powers, supra note 6, at 1339. For example, the Supremacy Clause denies supremacy to "Laws" made outside the "single, finely wrought and exhaustively considered, procedure" set forth in Article I, Section 7. I.N.S. v. Chadha, 462 U.S. 919, 951 (1983).
}

${ }^{155}$ James Madison, Notes on the Constitutional Convention (June 15, 1787), in 1 FARRAND'S RECORDS, supra note 70, at 245.

${ }^{156} I d$.

${ }^{157}$ See supra notes 116-18 and accompanying text. Moreover, when the Convention initially adopted the Supremacy Clause, the procedures for enacting federal statutes had not yet been clearly established. See James Madison, Notes on the Constitutional Convention (July 17, 1787), in 2 FARRAND'S RECORDS, supra note 65, at 28. Thus, it would be surprising if the Clause's reference to "the Legislative Acts of the U.S. made by virtue $\&$ in pursuance of the articles of Union," id., was meant to refer solely to laws made in accordance with federal lawmaking procedures.

${ }^{158}$ James Madison, Notes on the Constitutional Convention (Aug. 6, 1787), in 2 FARRAND's RECORDS, supra note 65, at 183 (emphasis added).

${ }^{159}$ U.S. CONST. art. VI, cl. 2. 
passed by both houses of Congress and presented to the President. ${ }^{160}$ Thus, if the Supremacy Clause was meant to confer supremacy on all "Laws of the United States" enacted by Congress and the President, then the qualifying language immediately following this reference was simply unnecessary. Second, the Supremacy Clause refers to "Laws" "made in Pursuance" of "[t]his Constitution." "This Constitution" most naturally refers to the entire Constitution, not just Article I, Section 7.

Those who ratified the Constitution expressed this understanding. As discussed, George Nicholas of Virginia read the Clause to encompass only those federal statutes "made in pursuance of or in conformity to the particular powers given by the constitution." ${ }^{161}$ Similarly, Thomas McKean explained at the Pennsylvania Ratifying Convention:

The meaning which appears to be plain and well expressed is simply this, that Congress have the power of making laws upon any subject over which the proposed plan gives them a jurisdiction, and that those laws, thus made in pursuance of the Constitution, shall be binding upon the states. ${ }^{162}$

Significantly, neither Professor Bickel nor any other commentator cites even a single remark from the founding era expressing the more restrictive view that "Laws ... made in Pursuance" of "this Constitution" refers solely to laws enacted according to federal lawmaking procedures.

Focusing on additional language in the Supremacy Clause, David Currie suggests an alternative interpretation that he believes "furnishes a powerful argument against judicial review of Acts of Congress." ${ }^{163}$ This interpretation contrasts the language used by the Clause to describe "Laws," on the one hand, and "Treaties," on the other. As discussed, the Clause recognizes "Laws ... made in Pursuance" of "[t]his Constitution" as "the supreme Law of the Land." "Yet the same clause also gives supremacy to all Treaties made, or which shall be made, under the Authority of the United States."'164 According to Professor Currie, "this provision embraces treaties made both before and after adoption of the Constitution." ${ }^{165}$ In his view, "the contrast strongly suggests that the reference to laws made in pursuance of 'this Constitution' was meant to distinguish those made under the Articles of Confederation." ${ }^{166}$ Thus, Professor Currie suggests that the phrase "Laws ...

${ }^{160}$ U.S. CONST. art. I, § 7.

${ }^{161}$ See supra note 122 and accompanying text.

${ }^{162}$ Debates of the Pennsylvania Convention (Nov. 28, 1787), in 2 THE DOCUMENTARY HiSTORY OF THE RATIFICATION OF THE CONSTITUTION 416-17 (Merrill Jensen ed., 1976).

${ }^{163}$ DAVID P. CURRIE, THE CONSTITUTION IN THE SUPREME COURT: THE FIRST HUNDRED YEARS 1789-1888, 73 (1985).

${ }^{164} I d$. at 72.

${ }^{165} I d$.

${ }^{166}$ Id. at 72-73. See also Michael J. Klarman, How Great Were the "Great" Marshall Court Decisions?, 87 VA. L. REV. 1111, 1119 (2001) ("'In Pursuance thereof' means `after,' not `consistent with."'); Van Alstyne, supra note 153, at 21 (suggesting that the phrase might "mean merely that only those statutes adopted by 
made in Pursuance" of "[t]his Constitution" was solely a temporal reference with few implications for judicial review.

There are several difficulties, however, with this interpretation. First, there is no real evidence that the Founders understood the phrase in this sense. As originally adopted by the Convention, the Supremacy Clause provided that "the legislative acts of the United States made by virtue and in pursuance of the articles of Union and all Treaties made and ratified under the authority of the United States shall be the supreme law of the respective States." ${ }^{167}$ The additional language regarding treaties upon which Professor Currie relies was not added until the end of the Convention out of an abundance of caution. In order to avoid ambiguity, Madison moved to amend the phrase "all Treaties made under the authority of the U.S."168 to read "all Treaties made, or which shall be made, under the Authority of the United States."169 According to Madison's notes, this change was adopted without objection and was simply "meant to obviate all doubt concerning the force of treaties preexisting, by making the words 'all treaties made' to refer to them, as the words inserted would refer to future treaties."170 Thus, it seems unlikely that a phrase originally adopted on July 17, 1787 to describe "Laws" was intended to differentiate itself from a phrase subsequently adopted on August 25, 1787 to describe "Treaties."

Second, even if the phrase was designed in part for this purpose, there is no indication that the language used to qualify "Laws" was intended to have solely temporal significance. In fact, there is significant evidence to the contrary. As discussed above, the text, history, and structure of the Constitution suggest that the Founders understood "Laws ... made in Pursuance" of "[t]his Constitution" to refer to statutes within the scope of Congress' enumerated powers. Thus, even assuming that the Supremacy Clause was intended to distinguish pre-existing "Treaties" from newly-enacted "Laws," the Clause was also understood more generally to condition the supremacy of federal statutes on adherence to the limits of Congress' enumerated powers. Contrary to Professor Currie's suggestion, the two functions are not mutually exclusive.

Third, the distinct language relating to "Laws" and "Treaties" may actually support judicial review of federal statutes. The Founders understood that "Laws" and "Treaties" would serve different purposes, and therefore established distinct procedures to govern their adoption. ${ }^{171}$ Treaties

Congress after the re-establishment and reconstitution of Congress pursuant to the Constitution itself shall be the supreme law of the land").

${ }^{167}$ Journal of the Constitutional Convention (July 17, 1787), in 2 FARRAND'S RECORDS, supra note 65, at 22.

${ }^{168}$ James Madison, Notes on the Constitutional Convention (Aug. 23, 1787), in 2 FARRAND'S RECORDS, supra note 65 , at 389 .

${ }^{169}$ U.S. CONST. art. VI, cl. 2 (emphasis added); see James Madison, Notes on the Constitutional Convention (Aug. 25, 1787), in 2 FARRAND'S RECORDS, supra note 65, at 417.

${ }^{170}$ James Madison, Notes on the Constitutional Convention (Aug. 25, 1787), in 2 FARRAND'S RECORDS, supra note 65, at 417.

${ }^{171}$ See Clark, Federal Common Law, supra note 6, at 1331 (noting "the specificity of, and the purposeful variations among, the procedures prescribed by the Constitution for adopting the 'Constitution,' 'Laws,' and 'Treaties"'). 
concern our external relations with foreign nations, whereas laws generally focus on domestic matters. Although the Founders assigned nearly complete power over foreign relations to federal officials, ${ }^{172}$ they were simply unwilling to delegate similarly broad authority over internal affairs to the new federal government. ${ }^{173}$ Given the distinct functions that "Laws" and "Treaties" were meant to perform, it is not surprising that the Constitution expressly conditions the supremacy of federal statutes on adherence to the limits of federal power. ${ }^{174}$

\section{Reassessing the Double Standard of Judicial Review}

The conditional nature of the Supremacy Clause undercuts modern suggestions that the Clause authorizes judicial review of state law alleged to conflict with federal law, but does not authorize judicial review of federal statutes alleged to exceed the scope of Congress' enumerated powers. By the terms of the Clause, whenever state law contradicts a federal statute, courts can resolve the conflict only by inquiring whether the federal statute was "made in Pursuance" of the Constitution. An affirmative answer means that the statute constitutes "the supreme Law of the Land," and that courts must disregard contrary state law. A negative answer, by contrast, means that courts have no warrant to displace state law.

As discussed, proponents of the political safeguards approach urge courts to abandon judicial review of federal statutes alleged to exceed the scope of Congress' enumerated powers, but to continue judicial review of state law alleged to conflict with such statutes. In their view, "[t]he prime function envisaged for judicial review - in relation to federalism - was the maintenance of national supremacy against nullification or usurpation by the individual states." ${ }^{175}$ In a recent article,

${ }^{172}$ See Clark, supra note 52, at 1294-99; see also THE FEDERALIST No. 42, at 264 (James Madison) (Clinton Rossiter ed., 1961) ("If we are to be one nation in any respect, it clearly ought to be in respect to other nations."). Even antifederalists like Thomas Jefferson considered "it indispensably necessary that with respect to everything external we be one nation firmly hooped together."' Letter from Thomas Jefferson to James Madison (Oct. 8, 1786) in CHARLes WARREN, THE MAKING OF THE CONSTITUTION 46 (1937). But cf. Curtis A. Bradley \& Jack L. Goldsmith, Customary International Law as Federal Common Law: A Critique of the Modern Position, 110 HARV. L. REV. 815, 863 (1997) (citations omitted) (stating that "the natural inference is that Article I, Section 10's self-executing limitations on state power in foreign relations are exhaustive and that other foreign relations activities fall within the concurrent authority of the state and federal governments until the federal political branches exercise their foreign relations powers in a manner that preempts state law").

${ }^{173}$ Clark, Federal Common Law, supra note 52, at 1260.

${ }^{174}$ This is not to say that there are no constraints on the federal government's ability to expand its authority through the treaty-making process. See Reid v. Covert, 354 U.S. 1, 16 (1957) (stating that "no agreement with a foreign nation can confer power on the Congress, or on any other branch of Government, which is free from the restraints of the Constitution").

${ }^{175}$ Wechsler, supra note 3, at 559; see supra notes 13-19 and accompanying text. Even Professors Prakash and Yoo seem to accept this view. See Prakash \& Yoo, Puzzling Persistence, supra note 25, at 1492 ("While judicial review arose in the context of protecting the national government from the states, this development still shows that the idea of courts invalidating legislation at odds with the Constitution was nowhere near as unfamiliar to the Framers as some might think."). 
Larry Kramer has reiterated and sharpened this thesis. Professor Kramer believes that "the Framers clearly decided to adopt judicial review as a device for controlling state laws,"176 but that "the power of courts to review federal legislation was left unaddressed." ${ }^{177}$ Kramer identifies the Supremacy Clause as the reason for this dichotomy. He characterizes the Clause as "[a]n express command for judges to prefer federal to state law." ${ }^{178}$ He maintains that after adopting of the Supremacy Clause, "the delegates assumed the existence of judicial review over state laws in their deliberations." ${ }^{179}$ In his view, however, "[n]o similar decision was made to authorize judicial review of federal legislation." ${ }^{180}$ Indeed, Kramer asserts that the Founders not only failed to authorize judicial review of federal statutes, but affirmatively "believed that the provisions delegating powers [to Congress] were not proper subjects for judicial involvement." ${ }^{181}$ For these reasons, Kramer concludes that the Founders envisioned judicial review only with respect to state law. ${ }^{182}$

Professor Kramer's account fails to appreciate the conditional nature of the Supremacy Clause. "As is evident from its text, ... the Supremacy Clause enshrines as the supreme Law of the Land' only those Federal Acts that accord with the constitutional design. Appeal to the Supremacy Clause alone merely raises the question whether a law is a valid exercise of the national power." ${ }^{183}$ Thus, in every case, before a court can recognize a federal statute as "the supreme Law of the Land," it must review claims that the statute in question was not "made in Pursuance" of the Constitution. ${ }^{184}$

${ }^{176}$ Kramer, We the Court, supra note 4, at 61.

${ }^{177}$ Id. at 67.

${ }^{178}$ Id. at 63.

${ }^{179}$ Id. at $63-64$.

${ }^{180}$ Id. at 64.

${ }^{181} I d$. at 125 .

${ }^{182}$ See id. at 64; Kramer, Politics, supra note 4, at 242-43. In a sense, modern scholarship has attempted to constitutionalize Justice Holmes' well-known aphorism: "I do not think the United States would come to an end if we lost our power to declare an Act of Congress void. I do think the Union would be imperiled if we could not make that declaration as to the laws of the several States." OLIVER WENDELL HOLMES, Law and the Court, in COLlected LEGAL PAPERS 291, 295-96 (1920). Holmes himself, of course, understood the Constitution to permit judicial review of both federal and state law.

${ }^{183}$ Alden v. Maine, 527 U.S. 706, 731 (1999) (citations omitted).

${ }^{184}$ Cf. Prakash \& Yoo, Puzzling Persistence, supra note 25, at 1468 ("If a state law conflicts with a federal law but the federal law itself is unconstitutional, then the state court may be under no Article VI obligation to invalidate the state law."); Rakove, supra note 89, at 1036 ("What is the Supremacy Clause about if it is not about something we would readily recognize as judicial review?"). John Harrison recognizes the argument that "a statute inconsistent with the Constitution is not adopted pursuant to it," but suggests this reasoning "beg[s] the question posed by the possibility that a statute and the Constitution can be inconsistent, which is whether the Constitution's implicit rule is that it prevails when in conflict with a statute." Harrison, supra note 138 , at 346 n.48. 
In short, the Supremacy Clause provides an express textual basis for judicial review of federal statutes alleged to exceed the scope of federal powers because such review is a prerequisite to judicial review of state law under the Clause. ${ }^{185}$

Recalling the conditional nature of federal supremacy helps to explain events at the Constitutional Convention that Professor Kramer finds puzzling. For example, Kramer observes that immediately after the defeat of the congressional negative, "Luther Martin moved to incorporate into the Constitution the proposed Supremacy Clause from the defeated New Jersey Plan." ${ }^{186}$ According to Kramer:

Martin's decision to move this amendment after the legislative veto had already been defeated is curious. If, as Sherman and Morris had suggested, a legislative veto was unnecessary because judicial review was already implicit, why move after the veto had been voted down to add a provision explicitly ordering state judges to treat federal law as supreme? And why do so if you are Luther Martin and interested mostly in keeping any limits on state power as weak as possible? ${ }^{187}$

Kramer speculates that Martin wanted "to ensure that the legislative veto was dead once and for all."188 But Martin's motion was more than a defensive maneuver. Martin sought adoption of the Supremacy Clause for the same reason that William Paterson originally proposed it as part of the New Jersey Plan-to authorize courts to check federal as well as state power.

Kramer's mistake lies in reading the Supremacy Clause as a one-sided provision that solely favors the federal government at the expense of the states. In fact, the Clause was designed to be a double-edged sword - that is, an authorization for courts to keep both the federal government and the states within their proper spheres. The Clause requires courts to prefer federal statutes to state law, but only if the statutes in question were "made in Pursuance" of the Constitution. ${ }^{189}$ For this reason, Martin's motion was undoubtedly motivated, at least in part, by his desire to protect the states against unwarranted federal legislation. He knew that if Congress exceeded its constitutional powers, the Supremacy Clause-unlike the congressional negative-authorized courts to ignore the results and continue to apply state law. In short, the cost of federal supremacy was judicial review. Under these circumstances, it is not at all "curious" that Luther Martin-a delegate committed to

\footnotetext{
${ }^{185}$ Although Professors Prakash and Yoo invoke the Supremacy Clause in support of judicial review, they ultimately conclude "that judicial review did not directly arise from any particular provision, but instead followed from the concept of a limited, written Constitution and the existence of a judiciary." Prakash \& Yoo, Puzzling Persistence, supra note 25, at 1505. The text and history of the Supremacy Clause, however, suggest that the Founders understood the Clause to be an express authorization for both state and federal courts to engage in judicial review of federal statutes. See supra notes 47-128 and accompanying text.

${ }^{186}$ Kramer, We the Court, supra note 4, at 63.

${ }^{187} I d$

${ }^{188} I d$.

${ }^{189}$ U.S. CONST. art. VI, cl. 2.
} 
keeping "limits on state power as weak as possible"-moved that the Convention adopt the Supremacy Clause.

The conditional nature of the Supremacy Clause also sheds light on other matters that Professor Kramer finds difficult to explain. In discussing judicial review, Kramer recounts the Convention's consideration of a Council of Revision - a proposal to vest the power to veto federal legislation in the President and a convenient number of federal judges. ${ }^{190}$ James Wilson favored the proposal on the ground that judicial review might prove inadequate to protect against "encroachments on the people as well as on [the Judiciary]."191 Other delegates opposed the proposal on the ground that it would give judges too much power in conjunction with judicial review. For example, Luther Martin objected that because "the Constitutionality of laws ... will come before the Judges in their proper official character," putting judges on the Council of Revision would give them "a double negative." ${ }^{192}$ Likewise, George Mason thought that federal judges "could declare an unconstitutional law void," but should give "a free course" to "every law however unjust oppressive or pernicious, which did not come plainly under this description."193

Professor Kramer finds it "difficult to know what to make of this exchange." ${ }^{194} \mathrm{He}$ acknowledges that Wilson envisioned at least limited judicial review of federal statutes, and that Martin and Mason "seemed to assume a broader power." ${ }^{195}$ Because the Council of Revision was rejected and "no other motion was made pertaining to the role of judges," Kramer concludes that "we are left uncertain as to what role, if any, judicial review was expected to play."196 Given that some delegates clearly expected courts to perform judicial review, Kramer offers several possible explanations "why none of the advocates of judicial review thought to make a motion to add this power." ${ }^{197}$ He hypothesizes that these delegates either "did not think it important to incorporate the power into the Constitution[,]" or "believed any effort to add such a provision would fail."198 Kramer concludes that "[w]hatever the explanation, the power of [federal] courts to review federal legislation was left unaddressed." ${ }^{199}$

\footnotetext{
${ }^{190}$ See Kramer, We the Court, supra note 4, at 64-66.

${ }^{191}$ James Madison, Notes on the Constitutional Convention (July 21, 1787), in 2 FARRAND'S RECORDS, supra note 65 , at 73 .

${ }^{192} I d$. at $73,76$.

${ }^{193} I d$. at 78.

${ }^{194}$ Kramer, We the Court, supra note 4, at 66.

${ }^{195} I d$.

${ }^{196} I d$.

${ }^{197} I d$.

${ }^{198}$ Id. at 67.

${ }^{199}$ Id.
} 
Here again, Professor Kramer overlooks the dual role of the Supremacy Clause. Luther Martin had no reason to propose judicial review of federal statutes following rejection of the Council of Revision for the simple reason that he had already proposed-and the Convention had already approved-the Supremacy Clause. Having successfully urged the adoption of the Clause just four days earlier, Martin had every reason to expect that courts would exercise judicial review of federal statutes in the course of identifying "the supreme Law of the Land." That is the reason why, in opposing the Council of Revision, Martin confidently declared that "the Constitutionality of laws ... will come before the Judges in their proper official character." ${ }^{200}$ At that point in the Convention, another motion pertaining to judicial review would have been superfluous. In light of the Convention's decision to adopt the Supremacy Clause, it is simply not plausible to suggest that "the power of courts to review federal legislation was left unaddressed." ${ }^{201}$

Opponents of judicial review might respond that even if the Supremacy Clause authorizes courts to review the scope of federal power, the Clause does not specify the appropriate standard of review. Thus, commentators like Larry Kramer might argue that application of even the most deferential standard—such as rational basis scrutiny-would satisfy any requirement of judicial review. $^{202}$ To support this contention, those who disfavor judicial review might invoke the political safeguards of federalism. ${ }^{203}$ According to this argument, the states need judicial protection from only the most arbitrary and irrational federal statutes because the constitutional structure permits states to protect their prerogatives in the lawmaking process. As one justice recently put it, "Congress, not the courts, must remain primarily responsible for striking the appropriate state/federal balance." 204

At the outset, it is not clear why the existence of structural safeguards designed to protect the states against the enactment of unconstitutional federal measures constitutes an excuse for upholding such measures. In this sense, "the political safeguards argument has always been something of a non sequitur." 205 As Michael Dorf points out, "[g]ranting that Congress will rarely act in a way that

${ }^{200}$ James Madison, Notes on the Constitutional Convention (July 21, 1787), in 2 FARRAND'S RECORDS, supra note 65 , at 76 .

${ }^{201}$ Kramer, We the Court, supra note 4, at 67.

${ }^{202}$ Cf. Kramer, Politics, supra note 4, at 291 (urging the Supreme Court to apply no more than "rational basis scrutiny to questions regarding the limits of Congress's power under Article I"); see United States v. Morrison, 529 U.S. 598, 628 (2000) (Souter, J., dissenting) ("The business of the courts is to review the congressional assessment, not for soundness but simply for the rationality of concluding that a jurisdictional basis exists in fact."); id. at 663 (Breyer, J., dissenting) (agreeing that "the Court's traditional `rational basis' approach is sufficient").

${ }^{203}$ See supra notes $11-46$ and accompanying text.

${ }^{204}$ Morrison, 529 U.S. at 660 (Breyer, J., dissenting).

${ }^{205}$ Dorf, supra note 21 , at 747 . The political safeguards approach is a bit like arguing that courts should uphold federal statutes that invade the President's constitutional prerogatives because the Constitution gives the President a role in the lawmaking process. The Supreme Court rejected this approach in I.N.S. v. Chadha, 462 U.S. 919 (1983), by invalidating the legislative veto notwithstanding the President's power to veto the offending statute. 
directly threatens state sovereignty, one important purpose of a Constitution is to provide resistance precisely in the extreme cases when the safeguard of representative government fails." 206

More fundamentally, if the Founders had regarded the political safeguards as sufficient to protect the states' prerogatives, then it is difficult to explain their vehemence in insisting that the congressional negative "would disgust all the States," ${ }^{207}$ and that the states would "[n]ever agree to be bound hand \& foot in this manner." ${ }^{208}$ Presumably, the Founders would have been satisfied that the states' role in the composition and selection of the national government would prevent Congress from exceeding its proper authority. In fact, the Founders were not content to rely exclusively on the political safeguards of federalism. Rather, they adopted the Supremacy Clause as an additional mechanism to check federal power.

From this perspective, restricting courts to "rational basis" review of federal statutes would defeat one of the central functions of the Supremacy Clause. As discussed, the Clause enlisted courts, not merely to uphold the supremacy of federal law, but also to keep the federal government within its proper sphere. Under the Constitution, federal courts have life tenure and salary protection, and thus enjoy significant independence from the political branches. State courts have similar, and arguably greater, independence from Congress. Such independence was undoubtedly one of the reasons why the Founders ultimately chose courts-rather than Congress or the President - to keep the federal government and the states within their respective spheres. Thus, courts could not limit themselves to rational basis scrutiny of federal statutes without effectively surrendering to Congress one of their essential functions under the Supremacy Clause. ${ }^{209}$

\section{Historical Examples}

Several prominent Supreme Court decisions recognize that courts must review the constitutionality of federal statutes in order to perform their role under the Supremacy Clause. Although the Court has placed greatest reliance on the Clause in cases involving conflicts between federal statutes and positive expressions of state law, the Court has also invoked the Clause to support judicial review of the scope of federal power more broadly. In all of these cases, the Court

${ }^{206}$ Dorf, supra note 21, at 747-48.

${ }^{207}$ James Madison, Notes on the Constitutional Convention (July 17, 1787), in 2 FARRAND'S RECORDS, supra note 65, at 28.

${ }^{208}$ James Madison, Notes on the Constitutional Convention (Aug. 23, 1787), in 2 FARRAND's RECORDS, supra note 65 , at 391.

${ }^{209}$ See Oregon v. Mitchell, 400 U.S. 112, 204 (1970) (Harlan, J., concurring in part and dissenting in part) ("Although Congress' expression of the view that it does have power . . . is entitled to the most respectful consideration by the judiciary, coming as it does from a coordinate branch of government, this cannot displace the duty of this Court to make an independent determination whether Congress has exceeded its powers.") (footnote omitted). Of course, recognizing that courts should exercise independent judgment in reviewing the scope of federal powers under the Supremacy Clause does not address whether courts should adopt a broad or narrow view of such powers. Thus, it is possible that a court exercising independent judgment would interpret the Commerce Clause in light of modern conditions to give Congress relatively broad power. 
has suggested that ascertaining whether a federal statute was "made in Pursuance" of the Constitution is an essential step in applying the Supremacy Clause.

Two early cases illustrate the role of the Supremacy Clause in resolving conflicts between positive state law and federal statutes: McCulloch v. Maryland ${ }^{210}$ and Gibbons v. Ogden. ${ }^{211}$ In McCulloch, the Supreme Court upheld a federal statute chartering the Bank of the United States, and in the process broadly construed Congress' power "[t]o make all Laws which shall be necessary and proper for carrying into Execution" its enumerated powers. ${ }^{212}$ For this reason, McCulloch is justly regarded as one of the most important nationalist rulings handed down by the Marshall Court. Commentators, however, typically overlook another important aspect of the decision: its reliance on the Supremacy Clause to support judicial review of the scope of Congress' enumerated powers.

McCulloch was sparked by a Maryland statute attempting to tax the operations of the Bank. Thus, the case presented an apparent conflict between federal and state law. As Chief Justice Marshall observed, "the conflicting powers of the general and state governments must be brought into view, and the supremacy of their respective laws, when they are in opposition, must be settled." 213 McCulloch did not resolve this question simply by declaring the federal statute to be "the supreme Law of the Land." Rather, the Court explained that the federal statute was "supreme" only if it was made in pursuance of the Constitution. ${ }^{214}$ In other words, McCulloch expressly recognized that the validity of Maryland's tax turned on the constitutionality of the federal statute incorporating the Bank.

Accordingly, Marshall declared that the "first question made in this case is-has congress power to incorporate a bank?"215 The Supreme Court's resolution of this question is familiar ground. After extended discussion, the Court held that Congress has implied power to incorporate a bank, ${ }^{216}$ and that the Necessary and Proper Clause does not limit-but rather augments-such power. ${ }^{217}$ Review of the Court's opinion reminds us, however, that the Court did not undertake judicial review of the federal statute in isolation. Rather, the Court regarded such review as an essential step in its application of the Supremacy Clause. The Court began its analysis, for example, by declaring that

${ }^{210}$ McCulloch v. Maryland, 17 U.S. (4 Wheat.) 316 (1819).

${ }^{211}$ Gibbons v. Ogden, 22 U.S. (9 Wheat.) 1 (1824).

${ }^{212}$ U.S. CONST. art. I, § 8, cl. 18.

${ }^{213}$ McCulloch, 17 U.S. at 405.

${ }^{214} I$. at 406 ("The government of the United States, . . . though limited in its powers, is supreme; and its laws, when made in pursuance of the constitution, form the supreme law of the land.").

${ }^{215} I d$. at 401.

${ }^{216}$ Id. at $406-11$.

${ }^{217}$ Id. at 411-21. See Rachel E. Barkow, More Supreme than Court? The Fall of the Political Question Doctrine and the Rise of Judicial Supremacy, 102 ColuM. L. REV. 237, 252 (2002) ("The [McCulloch] Court described its role as policing the boundaries of legislative power, not dictating legislative conclusions within those bounds."). 
"the government of the Union, though limited in its powers, is supreme within its sphere of action." ${ }^{218}$ Although the Court acknowledged that the Constitution does not give Congress express power to incorporate a bank, it found such power to be an appropriate means of executing Congress' "great powers, to lay and collect taxes; to borrow money; to regulate commerce; to declare and conduct a war; and to raise and support armies and navies." ${ }^{219}$ Thus, invoking the language of the Supremacy Clause, the Court concluded that "it is the unanimous and decided opinion of this court, that the act to incorporate the Bank of the United States is a law made in pursuance of the constitution, and is a part of the supreme law of the land."220

Had the McCulloch Court reached a contrary conclusion, no further inquiry would have been necessary to uphold the Maryland statute. ${ }^{221}$ Having found the federal statute to constitute "the supreme Law of the Land," however, the Court proceeded to inquire "[w]hether the state of Maryland may, without violating the constitution, tax [the Bank]." ${ }^{222}$ The Court held that it may not. The Court found that "the power to tax involves the power to destroy." ${ }^{223}$ Thus, Maryland's attempt to tax (i.e., destroy) the Bank of the United States conflicted with the federal statute establishing the Bank. In the case of such "plain repugnance" between a state law and a federal statute made in pursuance of the Constitution, the Supremacy Clause requires state law to yield. ${ }^{24}$ According to the Court, this is "the unavoidable consequence of that supremacy which the constitution has declared." 225

Gibbons v. Ogden ${ }^{226}$ provides a similar example. The case involved a conflict between a

${ }^{218}$ McCulloch, 17 U.S. at 405.

${ }^{219} I d$. at 407. The Court also thought it significant that "[t]he power now contested was exercised by the first congress elected under the present constitution." Id. at 401; see Marsh v. Chambers, 463 U.S. 783, 787-88 (1983) (rejecting an Establishment Clause challenge to the use of a legislative chaplain in part because "the First Congress, as one of its early items of business, adopted the policy of selecting a chaplain to open each session with prayer").

${ }^{220}$ McCulloch, 17 U.S. at 424 (emphasis added). Conversely, the Court expressly acknowledged that the Supremacy Clause operates as a constraint on federal power. According to the Court, "should congress, under the pretext of executing its powers, pass laws for the accomplishment of objects not intrusted to the government; it would become the painful duty of this tribunal, should a case requiring such a decision come before it, to say, that such an act was not the law of the land." Id. at 423.

${ }^{221}$ See Akhil Reed Amar, Of Sovereignty and Federalism, 96 YALE L.J. 1425, 1514 (1987) ("The clear implication of this way of structuring the analysis ... is that if the Bank had been unconstitutionally chartered, then Maryland could have taxed it."); see also Akhil Reed Amar, Intratextualism, 112 HARV. L. REV. 747, 749-59 (1999) (providing a detailed and nuanced account of McCulloch).

${ }^{222}$ McCulloch, 17 U.S. at 425.

${ }^{223}$ Id. at 431 .

${ }^{224} I d$.

${ }^{225}$ Id. at 436 .

${ }^{226}$ Gibbons v. Ogden, 22 U.S. (9 Wheat.) 1 (1824). 
New York statute granting an exclusive right to navigate all waters within the state's jurisdiction, and a federal statute authorizing ships to navigate the waters between New York and New Jersey. New York courts upheld the state statute and enjoined its violation. On appeal, the Supreme Court resolved the conflict between state and federal law by reference to the Supremacy Clause. The Court emphasized that the Constitution declares "the supremacy not only of itself, but of the laws made in pursuance of it." ${ }^{227}$ Thus, in every case in which state laws "interfere with, or are contrary to the laws of Congress, made in pursuance of the constitution," ${ }^{228}$ the federal statute prevails.

Accordingly, the outcome of the case turned on whether the federal statute in question was "made in Pursuance" of the Constitution. In a more frequently cited portion of the opinion, Gibbons interpreted the Commerce Clause to determine whether Congress had constitutional power to enact the statute. The Court held "that 'commerce,' as the word is used in the constitution, comprehends navigation," 229 and that Congress' power to regulate commerce "among" the several states refers to "commerce which concerns more States than one." ${ }^{230}$ The federal statute authorized navigation between New York and New Jersey, and therefore fell within the Congress' commerce power. Because the statute thus qualified as "the supreme Law of the Land," the Court held that contrary state law "must yield."231

Several other cases invoked the Supremacy Clause to support judicial review of federal statutes even in the absence of an obvious conflict with state law. In Hayburn's Case, ${ }^{232}$ for example, the Supreme Court considered the constitutionality of a federal statute requiring federal circuit courts to entertain claims by injured veterans for federal pensions under the Invalid Pensions Act of $1792 .^{233}$ Under the Act, courts were required to determine whether a petitioner met the statutory qualifications, and submit the names of successful claimants to the Secretary of War. The Secretary, in turn, was required to place these names on the pension list except in cases of "imposition or mistake." Although Congress mooted the case by changing the law, the Court reporter set forth "the reasons assigned by the [lower court] judges, for declining to execute the first act of Congress." 234

For example, Justices Wilson and Blair, sitting on the circuit court for the District of Pennsylvania, concluded that the Act was unconstitutional and that the court could not implement the Act. The court reasoned that the "constitution is 'the supreme law of the land,"' and that "all judicial officers of the United States are bound, by oath or affirmation, to support"' this supreme

${ }^{227}$ Id. at 210 .

${ }^{228} I d$. at 211.

${ }^{229}$ Id. at 190 .

${ }^{230} I d$. at 194.

${ }^{231}$ Id. at 211.

${ }^{232}$ Hayburn's Case, 2 U.S. (2 Dall.) 408 (1792).

${ }^{233}$ Act of Mar. 23, 1792, ch. 11, 1 Stat. 243.

${ }^{234}$ Hayburn's Case, 2 U.S. at 410. 
law. ${ }^{235}$ The court concluded that the Act violated the constitutional separation of powers and was "radically inconsistent with the independence of that judicial power that is vested in the courts."236 Faced with the choice of acting "contrary either to the obvious directions of congress, or to a constitutional principle, in our judgment equally obvious,"237 the court chose to follow the Constitution. $^{238}$

A decade later, in Marbury v. Madison, ${ }^{239}$ the Supreme Court found Congress' attempt to confer original jurisdiction on the Supreme Court to issue a writ of mandamus unconstitutional under Article III. Although not central to its reasoning, the Court invoked the Supremacy Clause at the end of its opinion to support judicial review:

It is also not entirely unworthy of observation, that in declaring what shall be the supreme law of the land, ... not the laws of the United States generally, but those only which shall be made in pursuance of the constitution, have that rank. Thus, the particular phraseology of the constitution of the United States confirms and strengthens the principle, supposed to be essential to all written constitutions, that a law repugnant to the constitution is void, and that courts, as well as other departments, are bound by that instrument. ${ }^{240}$

Hepburn v. Griswold ${ }^{241}$ placed even greater reliance on the Supremacy Clause. Hepburn presented the question "whether Congress has power to make notes issued under its authority a legal tender in payment of debts, which, when contracted, were payable by law in gold and silver coin.".242 The "law" Congress sought to displace in Hepburn was not state law in the modern sense, but rather the "general principles of commercial law" or the "law merchant." ${ }^{243}$ Such law gave the holder of a promissory note a "private right" to recover the sum specified by the note in gold and silver. ${ }^{244}$ The holder sued for payment and the debtor defended on the ground that a federal statute authorized

${ }^{235} I d$.

${ }^{236} I d$.

${ }^{237} I d$.

${ }^{238}$ Chief Justice Jay, Justice Cushing, and Justice Iredell all reached essentially the same conclusion sitting on the circuit courts. See id.

${ }^{239}$ Marbury v. Madison, 5 U.S. (1 Cranch) 137 (1803).

${ }^{240} I d$. at 180 .

${ }^{241}$ Hepburn v. Griswold, 75 U.S. (8 Wall.) 603 (1869).

${ }^{242} I d$. at 610.

${ }^{243}$ See Swift v. Tyson, 41 U.S. (16 Pet.) 1, 18 (1842); Clark, Federal Common Law, supra note 52, at 1280-81 (discussing Swift and the federal courts' application of the law merchant as a matter of "general law").

${ }^{244}$ Hepburn, 75 U.S. at 612. 
payment in United States notes. $^{245}$ The plaintiff replied that the statute was without legal force or effect because it exceeded Congress' constitutionally assigned powers. ${ }^{246}$

The Supreme Court did not pause to inquire whether the federal statute conflicted with state law per se. Rather, the Court proceeded to examine whether the Constitution authorized the statute in question. After quoting the Supremacy Clause in full, the Court explained: "Not every act of Congress . . . is to be regarded as the supreme law of the land; nor is it by every act of Congress that the judges are bound. This character and this force belong only to such acts as are 'made in pursuance of the Constitution."' ${ }^{247}$ On the merits, the Court concluded that Congress lacked express or implied power to make its notes legal tender for pre-existing debts. ${ }^{248}$ Accordingly, notwithstanding the federal statute, the Court held that the defendants lacked a valid excuse for failure to pay the note in gold and silver coin.

The Hepburn Court rejected the suggestion "that this is not a question for the court deciding a cause, but for Congress exercising the power." ${ }^{249}$ In the Court's view, permitting Congress to determine the extent of its own powers "would completely change the nature of American government." 250

It would convert the government, which the people ordained as a government of limited powers, into a government of unlimited powers. It would confuse the boundaries which separate the executive and judicial from the legislative authority. It would obliterate every criterion which this court, speaking through the venerated Chief Justice..., established for the determination of the question whether legislative acts are constitutional or unconstitutional. ${ }^{251}$

Accordingly, the Court concluded that the federal statute was not "made in pursuance" of the Constitution and could not alter the private rights of the parties before the Court. ${ }^{252}$

Since these early cases were decided, courts and commentators have largely forgotten the conditional nature of the Supremacy Clause and now generally take for granted both federal supremacy and judicial review. Thus, one need not cite the Supremacy Clause for the seemingly self-evident proposition that federal statutes trump contrary state law. Nor do courts invoke the Supremacy Clause-as Chief Justice Marshall did in Marbury v. Madison and McCulloch $v$.

\footnotetext{
${ }^{245} I d$.

${ }^{246} I d$

${ }^{247} I d$. at 611.

${ }^{248} I d$. at $613-26$.

${ }^{249} I d$. at 617.

${ }^{250} I d$. at 618 .

${ }^{251} I d$.

${ }^{252}$ See id. at 626.
} 
Maryland - as authority for judicial review of federal statutes. This is why modern commentators like Jesse Choper and Larry Kramer see no contradiction in simultaneously urging courts to uphold the supremacy of federal statutes over contrary state law, but to refrain from invalidating federal statutes that exceed the scope of Congress' enumerated powers. Upon examination, however, the Supremacy Clause does not permit courts to separate judicial review in this fashion. The Clause establishes, in pertinent part, that state law provides the governing rule of decision in all cases unless and until preempted by a contrary "Law[ ] of the United States made in pursuance" of the Constitution. The conditional nature of the Supremacy Clause means that courts should recognize federal statutes as "the supreme Law of the Land" if—-but only if — they first review and reject any constitutional challenges to the federal statute at issue.

Conclusion

Contrary to modern assumptions, the Supremacy Clause provides a textual basis for judicial review of federal statutes alleged to exceed the scope of Congress' enumerated powers. By the terms of the Clause, federal statutes qualify as "the supreme Law of the Land" only if they are "made in Pursuance" of "[t]his Constitution." By conditioning the supremacy of federal statutes on their constitutionality, the Clause simultaneously performs two distinct functions: ensuring the supremacy of federal law and upholding the limits of federal power. Although commentators generally regard the Clause as concerned solely with the first function, the second function was at least as important to those who framed and ratified the Supremacy Clause. Properly understood, the Clause does not permit courts to separate judicial review of state law alleged to conflict with federal statutes from judicial review of the federal statutes themselves. Rather, the text, history, and structure of the Constitution suggest that the Supremacy Clause necessarily authorizes courts to review the constitutionality of federal statutes in the course of identifying "the supreme Law of the Land." 